\title{
Uncertainty in Entrepreneurship and Management Studies: A Systematic Literature Review
}

\author{
Giovanna Magnani ${ }^{1} \&$ Antonella Zucchella ${ }^{1}$ \\ ${ }^{1}$ Department of Economics and Management, University of Pavia, Italy \\ Correspondence: Giovanna Magnani, Department of Economics and Management, University of Pavia, Italy. \\ E-mail: g.magnani@unipv.it
}

Received: January 8, 2018

Accepted: February 10, 2018

Online Published: February 25, 2018

doi:10.5539/ijbm.v13n3p98

URL: https://doi.org/10.5539/ijbm.v13n3p98

\begin{abstract}
Despite the crucial role of uncertainty in entrepreneurship and management studies, the characteristics of uncertainty, its relationship with risk, and the sources of uncertainty affecting firms' activities still require investigation. Extant literature lacks systematization, and concepts like risk and uncertainty are interchangeably used. The issue of uncertainty is present in very different fields of research but with different nuances and sometimes conflicting approaches. This work contextualises the concept of uncertainty in strategic management and entrepreneurship, because in both fields actors make decisions impacting on the survival and long run performance of their organisations. These decisions take place in a context shrouded in either high risk or uncertainty. We systematically analyse 96 papers and 28 books, and purposely integrate the economics, entrepreneurship, and organizational perspectives into our review. We contribute to extant knowledge by systematizing the literature about uncertainty. Firstly, we disentangle its construct from the construct of risk. Secondly, we reveal its complex nature, as a context at the interface between the external and the internal environment. Finally, we link this conceptualisation of uncertainty to the formation of opportunities in the processes of strategic management and entrepreneurship.
\end{abstract}

Keywords: uncertainty, management, systematization

\section{Introduction}

Decision-making under risk and uncertainty characterises both the strategic management (Alvarez and Barney 2007) and the entrepreneurship fields (Gavetti 2005; McMullen \& Shepherd, 2006).

At the same time, in these two streams there is a gap in the understanding about the constructs of risk and uncertainty. According to Alvarez and Barney (2005) in both strategic management and entrepreneurship "risk and uncertainty are treated as if they were synonyms" (ibid. p. 778). An interesting case is represented by the emerging field of strategic entrepreneurship (SE from now on), which positions at the crossroads of entrepreneurship and strategic management, encompassing their entrepreneurial and managerial processes. Furthermore, in this recent stream, which builds on the foundations of its parent disciplines, risk and uncertainty are used either interchangeably or contradictorily (Kuratko \& Audretsch, 2009; Klein et al., 2012). According to some Authors (e.g. Hitt et al., 2000; Klein et al., 2013), SE is conceptualized as embedded in contexts of Knightian uncertainty. Others argue that risk and uncertainty characterize strategic management and entrepreneurship (Schendel \& Hitt, 2007), respectively.

We find this gap particularly relevant to address, because it lies at the foundations of two important disciplines. Strategic management and entrepreneurship refer to different processes within the firm's lifecycle: the former deals with the management of extant competitive advantage and the latter deals with the formation of opportunities. These processes can co-exist, as in the case of established firms, which contemporarily pursue strategizing in extant businesses and launching new ventures, intended as novel combinations (Schumpeter, 1934; Davidsson, 2015). Though addressing different issues, both processes involve making impactful decisions on the survival and the long run performance of the organisation (Hambrick 1983; Bourgeois, 1985). The long run orientation and the path changing potential (both for the organisation and for its environment) of strategic and entrepreneurial decisions make them likely to happen within a continuum that starts with "substantial risk" and ends with "pure Knightian uncertainty". This is the context where our contribution is framed. 
In Knight (1921), risk corresponds to a situation where a decision-maker is able to draw the frequency distribution of the outcomes of a range of future events. While a situation of uncertainty involves the decision-maker being confronted with the impossibility of assigning objective probabilities to each of the outcomes, nor - in extreme cases - knowing the likelihood of a set of events occurring. Building on this conceptual premise, we discuss how risk and uncertainty have been understood in management and entrepreneurship studies. This contribution aims at a better characterisation of uncertainty, through two steps: first, we aim at distinguishing uncertainty from risk (external characterisation). Second, we pursue an "internal characterisation" of uncertainty, discussing its sources and typologies.

In particular, since our work is centred on the firm and its strategic/entrepreneurial decisions, we embrace a classification of the sources of uncertainty which refers to conditions of the environmental contexts inside and outside the organisational boundaries. We depart from Kahneman and Tversky's (1982) fundamental phenomenology of uncertainty, according to which there are two types of uncertainty, viz. internal and external. The former relates to factors of the external environment that the decision-maker is not able to control, comprising also other actors' mental models. The latter, in contrast, refers to a lack of knowledge imputable to factors that are proper to the decision-maker, or to the firm when we consider group-level processes where cognition is shared. Internal uncertainty ultimately refers to the perceptual dimension of uncertainty (perceived uncertainty), which plays a vital role in the strategic management and entrepreneurial process.

The internal versus external distinction has merits in terms of categorisation, but it is not entirely convincing, because in our literature review some studies cannot be classified neatly in any of the two typologies mentioned. We systematically analyse 96 papers and 28 books and purposely integrate the economics, entrepreneurship, and organizational perspectives into our review. In doing so, we address the abovementioned gaps, both of which refer to the lack of an adequate characterisation of the construct of uncertainty.

The contributions of this paper to extant knowledge are twofold. Firstly, in reviewing the theoretical and empirical works on uncertainty, we systematize the state of knowledge on the characterization of uncertainty. We discuss the distinction between risk and uncertainty in the perspective of entrepreneurship and strategic management studies. Secondly, we overcome the usual phenomenology of uncertainty, based on the clear-cut distinction between internal and external uncertainty (Kahneman \& Tversky, 1982), and instead organise the literature according to a number of themes, emerging from our analysis. These themes suggest that uncertainty lies at the interface between external and internal sources. We also discuss uncertainty as a context for the formation of opportunities, arising at the mentioned interface of internal and external sources of uncertainty. This perspective is coherent with a strategic management and entrepreneurship framework and opens new research paths. We propose that managing at the interface of internal and external uncertainty involves engaging in a cognitive process of "internalizing" external sources of uncertainty through judgments regarding the potential opportunities they disclose. This, in turn, may trigger subsequent resource mobilization processes and confrontation with novel $/$ modified sources of uncertainty in a recursive way. We thus address a call for strong conceptual foundations in both strategic management and entrepreneurship studies (Kuratko \& Audretsch, 2009) and for robust models to analyse its processes (Kyrgidou \& Hughes, 2010).

\section{Method}

We conduct a systematic literature review (SLR) applying the methods described by Webster and Watson (2002) and the prescriptions by Jones and Gatrell (2014); Macpherson and Jones (2010); Petticrew and Roberts (2008); Tranfield et al. (2003). We employ SLR as a guiding tool (see Wang \& Chugh, 2014), as the ultimate aims of this review are to provide a characterisation of uncertainty and to offer insights for the field of strategic entrepreneurship.

We consider SRL appropriate for the purpose of this paper for the following reasons: (i) at the time of this study there is a wide amount of research on the topic of uncertainty, but the state of knowledge about what characterizes uncertainty remains equivocal; (ii) an accurate account of past research is necessary in order to facilitate further development in the analysis of uncertainty in the strategic management and entrepreneurship fields.

\subsection{Objectives and conceptual boundaries}

We begin our SLR by setting the research objectives and conceptual boundaries (Denyer \& Tranfield, 2008). The objectives are: (1) to characterise uncertainty with respect to the construct of risk; (2) to characterise uncertainty in terms of its sources, and discuss the relevant types; (3) to advance insights and avenues for future research for the strategic management and entrepreneurship field. 
The conceptual boundaries of our work are defined through the lenses of entrepreneurship and strategic management and address the role of uncertainty (versus risk) in the processes of opportunity formation, which are core to the birth and development/renewal over time of firms.

First, we conceptualize risk and uncertainty according to the Knightian seminal distinction between the two (Knight 1921). As mentioned, in this foundational work, risk corresponds to those situations where the decision-maker is able to draw the distributions of the outcomes of a group of events. Meanwhile, uncertainty corresponds to situations characterized by the impossibility of assigning objective probabilities to each of the outcomes and - in extreme cases - predicting whether one or more events will occur.

Second, we build on the already mentioned Kahneman and Tversky (1982) internal versus external distinction of uncertainty to bridge the perspective of entrepreneurship and strategic management with the cognitive theory of the firm. The context that arises from linking these fields is useful in characterizing risk against uncertainty, and to overcome any neat distinction between internal and external uncertainty types.

Exploring opportunities in uncertain contexts is both an individual and a firm-level (Agarwal et al., 2010) phenomenon. The firm-level aspect can be thus understood in the perspective of the cognitive theory of the firm, where organizations are characterized by "distributed cognition" (Boland \& Tenkasi, 1995): they are a "collective mind" (Weick and Roberts 1993), a system of "shared meanings" (see Nooteboom, 2005; Smircich, 1983). In management studies too, group-level processes - where shared mental models operate at the group level - describe this phenomenon (Knight et al., 1999).

The firm's ability to cope with uncertainty through the constant confrontation between external environment and managerial cognitive limits influences its ability to create opportunities (see Hitt et al., 2011).

\subsection{Literature Selection}

In order to gain a preliminary understanding of the amount of literature covering risk and uncertainty, we perform an exploratory search using ProQuest, IEEE Xplore, and Google Scholar. The starting point in time to retrieve contributions is 1921 when two of the most important works on risk and uncertainty were about to be published, i.e. Frank Knight's Risk Uncertainty and Profit, and John Maynard Keynes'A Treatise on Probability. We conduct a full-text search up until the beginning of 2016, using a set of keywords (see Appendix B) and then repeating the same search including the Boolean search operator "AND" for each of the former sentences combining "risk" AND "uncertainty" AND e.g. "management".

Searches using the above-mentioned keywords yielded more than 7.000 .000 results: an unmanageable number of papers to be reviewed, proving the amount of research on the topic of uncertainty and risk. At the same time, this huge realm of studies can explain the difficulty in achieving systematization in this field. Therefore, we decided to use specific inclusion and exclusion criteria (see Appendix B) in tune with the most recent SLR practices (see e.g. Nolan and Garavan 2016). According to these criteria, we select a set of journals - based on the ABS Academic Journals Quality Guide - where we searched the Title and Abstract using the key Boolean search terms of *uncertainty AND *risk. At this stage, we ended up with 22.734 papers of which 1100 were considered relevant in terms of contribution to understanding uncertainty in management (see Lee, 2009) according to our inclusion criteria. 1005 contributions - even though they contained the key search terms - did not provide a meaningful contribution to one or more objectives of our study, and were thus excluded. We ended up with 96 papers (see Appendix A for the list): 52 conceptual articles, 35 quantitative, 7 qualitative and 2 mixed-method studies. The total number of journals is 46,41 of which had an impact factor identified by Thomson ISI. Table 1 shows the distribution of articles listed according to the journal in which they have been published, together with the impact factor of the journal. We also decided to keep books (28 books and 1 book chapter) that were selected following the "go backward technique" (Watson and Watson 2002) (see Appendix C).

Table 1. List of Journals used in the SLR, Articles per Journal and Impact Factor

\begin{tabular}{lll}
\hline Subcategories and Journal Title & N. of papers & $\begin{array}{l}\text { Impact } \\
\text { factor }\end{array}$ \\
\hline General Management Journals & 4 & \\
Academy of Management Journal & 1 & 4,974 \\
Academy of Management Perspectives & 6 & 2,826 \\
Academy of Management Review & 6,895 \\
\hline
\end{tabular}




\begin{tabular}{lll}
\hline Administrative Science Quarterly & 5 & $7,057^{*}$ \\
Journal of Management & 5 & 6,862 \\
Journal of Management Studies & 5 & 3,277 \\
International Journal of Management and Decision Making & 1 & - \\
International Studies of Management and Organization & 1 & $1,71^{*}$ \\
Sloan Management Review & 1 & \\
Economics Journals & & $2,29 * *$ \\
American Economic Review & 3 & 0,914 \\
Cambridge Journal of Economics & 2 & 3,504 \\
Econometrica: Journal of the Econometric Society & 1 & 2,587 \\
Economic Journal & 1 & $0,49 *$ \\
Journal of Economic Issues & 1 & 0,919 \\
Journal of Economic Theory & 2 & 1,036 \\
Journal of Law, Economics, and Organization & 1 & 3,617 \\
Journal of Political Economy & 3 & 5,966 \\
Quarterly Journal of Economics & 1 & 1,190 \\
Review of Political Economy & 1 &
\end{tabular}

\section{Psychology Journals}

Annual Review of Psychology

Entrepreneurship and Small Business Management Journals

Entrepreneurship Theory and Practice

Journal of Business Venturing

Journal of International Entrepreneurship

Small Business Economics

Organization Studies Journals

Human Relations

Organization Science

\section{Social Science Journals}

Industrial and Corporate Change

Journal of Law and Economics

0,29

Risk Analysis

Sociology

\section{Operations Research and Management Science Journals}

Interfaces

Management Science

\section{International Business and Area Studies Journals}

International Business Review

Journal of International Business Studies

Journal of International Management 


\begin{tabular}{lll}
\hline Journal of Marketing & 1 & 3,8 \\
Journal of Marketing Research & 1 & 2,7 \\
Strategic Management Journals & 1 & 2,111 \\
Long Range Planning & 7 & 3,78 \\
Strategic Management Journal & & 6,033 \\
Finance Journals & 3 & 1,958 \\
Journal of Finance & & - \\
Journals not included in the ABS list & 1 & $-* * *$ \\
Natural Hazards & 1 & \\
Decisions in Economics and Finance & 1 & \\
Journal of Business & & \\
TOT Number of Journals $=\mathbf{4 6}$ & & \\
$*$ five-year impact factor & & \\
$* *$ two-year impact factor & & \\
$* * *$ The Journal of Business was edited from 1928 to 2006 & & \\
\hline
\end{tabular}

\section{Literature Analysis: The Characterization of Uncertainty}

The characterisation of uncertainty can be approached in two stages. Firstly, by setting boundaries between the construct of uncertainty and that of risk. Secondly, by discussing typologies of uncertainty.

We structure the review as follows. In order to characterize uncertainty versus risk, the first section analyses 36 papers, 12 books and 1 book chapter. Here we set out the probabilistic foundations of uncertainty and its relationship with risk. The second section, which is devoted to discussing themes about uncertainty and its typologies, analyses 43 works: conceptual papers and - among the empirical works - those providing a strong contribution in terms of conceptualizing uncertainty (see Appendix B), and 20 books. Here we systematize the literature under a series of emerging themes, overcoming the dichotomy between external and internal uncertainty. In fact, at the beginning of our literature review process our aim was to categorize the collected papers using Kahneman and Tversky's (1982) typology of internal versus external uncertainty. This fundamental typology - widely acknowledged in the literature - emerged as particularly suitable and intuitive according to our conceptual premises. Nonetheless, in doing so, we could not always clearly categorize the collected studies within either of the two types. Therefore, we decided to let the literature review process itself bring out emerging themes that become categories for analysis, viz. (1) uncertainty about the outcomes of external environment, (2), uncertainty about other actors' actions, (3) uncertainty as lack of knowledge, and (4) degrees of confidence to deal with uncertainty.

The third section of the paper, which provides a focus on the empirical literature, reviews and systematizes 28 papers. In this section, we devote special attention to the topic of perceived uncertainty. The latter emerges as particularly relevant to our conceptual frame as it highlights the complex interactions between environment and cognition (Gregoire et al., 2011). We analyse empirical studies according to the four themes mentioned above but also account for the different measurements and operationalizations of (perceived) uncertainty, as well as the levels of analysis undertaken by each study ${ }^{1}$.

Last, we discuss two core arguments that we believe can further advance strategic entrepreneurship research, i.e. (i) the need to understand decision-making at the interface of internal and external uncertainty, and (ii) how firms manage the intersection of internal uncertainty with external uncertainty.

\subsection{Characterizing Uncertainty versus Risk}

The inquiry regarding the relationship between uncertainty and risk is one of most controversial questions in the theoretical and methodological discourse adopted by various schools of thought.

In his Treatise on Probability, Keynes (1921) distinguishes among three types of probabilities: (i) a probability that is numerically indeterminate; (ii) probabilities that are numerically determinate; (iii) probabilities taking either the value of zero or one. The first type corresponds to a situation of uncertainty, while the third to certainty. Certainty can be reached when the so-called weight of the argument is high, i.e. when the amount of evidence (or knowledge) is high (Lawson 1987). In his seminal contribution, Knight (1921) distinguished three 
types of probability situations: a priori probabilities, statistical probabilities, and estimates. A priori probability concerns those "absolutely homogeneous classification of instances completely identical except for really indeterminate factors" (ibid p. 224). Statistical probability refers to "any high degree of confidence that the proportions found in the past will hold in the future is still based on an a priori judgment of indeterminateness" (ibid, p. 225). Estimates consist in the decision-maker's "judgment" about the occurrence of an instance. According to Knight (1921) there are two types of uncertainty:

i. A measurable one, when we can calculate a priori probabilities of outcomes thanks to the fact that we are able to group instances according to their similarities - and thus to draw the frequency distribution of the outcomes - or to group instances because they already happened in the past;

ii. An unmeasurable one, when we cannot calculate the probabilities of possible outcomes. In this case we are not able to group instances because they are unique: they neither bear similarities with others, nor occurred before. The probability in this case corresponds to the individual's judgment about the likelihood of the occurrence of an instance (estimate).

The first type of uncertainty is commonly referred to as risk, against which we can insure (LeRoy \& Singell, 1987). While the second cannot be insured against because of the presence of opportunism and moral hazard: uncertainty is rooted in a lack of knowledge regarding other actors' actions. The Knightian classification of probability typologies has been often interpreted as a differentiation between objective and subjective probabilities. For subjectivist theorists, probability corresponds to the so-called degree of belief in a given proposition or event (see e.g. Savage, 1954). In a nutshell, in economics, "Knightian risk" involves situations where all possible outcomes and their frequencies are known (Runde, 1998).

In management studies, risky investments correspond to a situation of Knightian risk meaning that the outcomes that will be generated out of a determinate market opportunity are known (Alvarez, 2007). In strategic management research, it is often assumed that executives associate risk with negative outcomes (March \& Shapira, 1987), or with the possible loss generated by an action (Penrose 1972). At the same time, much of the literature in strategic management uses the terms "risk" and "uncertainty" as synonyms (e.g. Balakrishnan \& Wernerfelt, 1986; Ghoshal, 1987; Miller \& Bromiley, 1990; Shane \& Eckhardt, 2003; Wernerfelt \& Karnani, 1987). When the concept of risk is associated with the "variability" in flows or returns, it overlaps with the construct of uncertainty as used in strategic management theory.

In the latter disciplines, uncertainty often refers to the unpredictability of environmental or organizational variables that impact on corporate performance (Miles \& Snow, 1978; Pfeffer \& Salancik, 1978) or to the inadequacy of information regarding these variables (Duncan, 1972; Galbraith, 1977). At the same time, it is assumed that risk arises because of a number of internal and external environmental factors to the firm; hence in this sense we speak about "sources" of risk. For instance, risk is related to sets of specific environmental (Ghoshal 1987; Miles and Snow 1978; Pfeffer \& Salancik, 1978), political (Fitzpatrick, 1983; Henisz, 2000; Miller, 1992; Truitt, 1974; Slangen \& Van Tulder, 2009), country-related (Aulakh \& Kotabe, 1997; Brown et al., 2015; Hill et al., 1990; Klein et al., 1990) or relational (Das \& Teng, 1996; Nooteboom et al., 1998) sources.

Some scholars have tried to "revert" situations of uncertainty into situations of risk. For instance, Bewley (2002) develops a formalized interpretation of Knightian uncertainty by assigning to unknown outcomes an initial probability of zero, which then - along the process of decision-making - can take non-zero values. However, it is also being argued that the conceptualization of risk and uncertainty shall not be confined to the sole application of the probability theory (Mousavi \& Gigerenzer, 2014).

In entrepreneurship research (see e.g. Covin \& Slevin, 1989; Gartner, 1990), entrepreneurial activity is described as "risk-taking", but it is still unclear whether scholars refer to risk or Knightian uncertainty.

On the one hand, the lack of semantic validity between risk and uncertainty suggests that the two constructs can (and should) be separated supporting the finding that risk and uncertainty have been repeatedly used as interchangeable concepts (see Liesch et al., 2011; Sanderson, 2012). On the other hand, some scholars attribute this concept ambiguity to the fact that strategic management actually involves dealing with - perhaps concurrent - situations of risk and uncertainty (see e.g. O'Reilly \& Tushman, 2008; 2013).

The emerging field of SE has - among its key research questions - the meaning and role of risk versus uncertainty: "while both fields focus on decision-making, strategic management looks at decision-making under conditions of risk, while entrepreneurship also looks at decision-making under Knightian uncertainty" (Klein et al., 2013, p. 781). The Authors also point out that in SE, "economic action takes place under conditions of Knightian uncertainty", under which "judgment, satisficing, biases and heuristics, experimentation and learning 
[...] are critically important" (ibid., p. 779). At the same time, Kuratko and Audretsch (2009) discuss entrepreneurship as "willingness to take calculated risks" and build on this premise when referring to strategic entrepreneurship.

The SE field is thus not immune from the ambiguous conceptualisation of uncertainty versus risk, though this issue is recognised as a "fundamental assumption" for strategic entrepreneurship (Klein et al. 2013). This may help to understand why some Authors argue that "the exact nature of this concept [strategic entrepreneurship] remains elusive" (Kuratko \& Audretsch, 2009, p.2).

We support the idea that risk and uncertainty are different contexts and they should not be treated as synonymous. Thus, in our opinion, there should not be any overlapping use of the two constructs, in order to overcome the above mentioned conceptual ambiguities. At the same time, we agree that risk and uncertainty are not mutually exclusive and also that - in a dynamic perspective - uncertainty can evolve into situations of risk and vice-versa.

Risk and uncertainty can thus be seen as belonging to a continuum (Hmieleski et al., 2015; Knight, 1921) and involving different degrees of judgment (Miller 2007) "ranging from straightforward to impossible" (ibid, p. 58). Entrepreneurial mindsets consist of (i) judgments about outcome expectancies - the so-called representations of external and internal factors (Mitchell et al., 2008) - and (ii) the "perception of the capability to pursue entrepreneurial opportunities" (ibid. p. 227). In particular, judgment may refer to the concept of opportunity evaluation (Wood \& McKelvie, 2015), i.e. the personal belief that a circumstance represents a desirable and feasible path (ibid).

The formation of opportunities can happen in situations of uncertainty and then - at the moment of committing resources for exploiting opportunities - may require judgements, based in conditions of risk. This is particularly true when the resources come from external investors, who need risk estimates before committing their capital into a venture or a project. Judgment can thus link situations of uncertainty and risk to contexts of opportunity exploration and exploitation (Korsgaard et al., 2015).

According to Klein et al. (2013), judgment is also key to strategic management. This confirms that bridging entrepreneurship and strategic management, as the emerging strategic entrepreneurship field aims for, provides an interesting and integrated perspective. At the same time, we contend that the persisting ambiguity surrounding risk and uncertainty can undermine the development of SE. A more robust characterisation of uncertainty versus risk sets the foundations for the understanding of the key dimensions in SE, i.e. the exploration and exploitation of opportunities (opportunity seeking behaviour) in conjunction with advantage-seeking behaviour, both of which simultaneously lie at the heart of strategic entrepreneurship processes.

The next sections focus on framing a characterisation of uncertainty based on finding typologies of uncertainty to then link this conceptualisation of uncertainty to the formation of opportunities, judgment processes and subsequent exploitation activities, thus highlighting the interconnections among uncertainty, cognition and opportunity formation.

\subsection{Characterizing Uncertainty: A Taxonomy}

We could not always clear-cut categorize the collected studies within either of the two types of uncertainty (internal and external) discussed in Kahneman and Tversky's (1982) typology. Therefore, building on these two fundamental types, we grouped the documents according to four manifestly emerging themes that we then considered new categories for further analyses (see Table 2): (1) uncertainty about the outcomes of external environment, (2), uncertainty about other actors' actions, (3) uncertainty as lack of knowledge, and (4) degrees of confidence to deal with uncertainty. These four themes enable the development of a novel taxonomy of uncertainty by aggregating the literature under recurrent emerging topics.

Table 2. Systematization of studies by themes and sources of uncertainty

\begin{tabular}{cll}
\hline Themes & \multicolumn{1}{c}{ Sources of uncertainty } & \multicolumn{1}{c}{ Scholars and years } \\
\hline & Presence of multiple outcomes & Luce and Raiffa 1957 \\
$\begin{array}{c}\text { Uncertainty about } \\
\text { the outcomes of } \\
\text { external }\end{array}$ & Impossibility in drawing outcomes' distribution & Alvarez 2007; Beker and Knudsen 2005; \\
environment & & Beckman et al. 2004; Hsu et al. 2012; Knight \\
& & $1921 ;$ Loasby 1976. Under the name of \\
& Impossibility to group instances & fundamental uncertainty (Post Keynesians: e.g. \\
\hline
\end{tabular}


Impossibility both to group outcomes and to draw their probability distribution

Ability to group instances but inability to assign definite probabilities to the occurrence of particular outcomes

Ability to group instances but inability to define the degree of confidence actors assign to the probabilities of the outcomes

Future states of the world cannot be anticipated and predicted

Exogenous shocks due to consumer's preferences and external technological change,

The inability to assert with certainty one or more of the following: (a) probability of outcomes of future events; (b) probability of future events, conditional to the realization of other events; (c) how to incorporate information in determining the probability of a future event; (d) how to conceptualize consequences of the occurrence of an event

Environmental uncertainty

Environmental complexity and dynamism

Perceived environmental uncertainty

Market uncertainty: imperfect information prevents actors from knowing how to behave and what to expect from their

The external environment in its objective dimensions

Unanticipated changes in the environment which affect an exchange

Technological uncertainty

Technical uncertainty

Secondary uncertainty (i) reflects a lack of knowledge about the actions of other economic actors, (ii) under the label of tertiary uncertainty

Behavioural uncertainty

Supplier uncertainty

Uncertainty about Competitors uncertainty

other actors' actions

Case probability

Organizational uncertainty

Status anxiety

Cultural uncertainty

Uncertainty associated with meeting one another for the first time

Quality uncertainty and transition uncertainty

Communicative uncertainty

Agents are uncertain of the model guiding their actions - part of this uncertainty is imputable to other actors in the economy

Uncertainty as lack A low "weight of the argument"

of knowledge
Knight 1921, Loasby 1976, under the name of pervasive uncertainty in Beker and Knudsen 2005

Baird and Thomas 1985; Conrath 1967; Mousavi and Gigerenzer 2014; von Gelderen et al. 2000

March and Simon, 1958

Duncan 1972

Penrose 1972; Pfeffer and Salancik 1978

Buckley and Carter, 1999

Humphreys and Berkley 1985 (p.258)

Abdi and Aulakh 2017; Anderson and Tushman 2001; John et al. 2003; Child 1972; Dill 1958; von Gelderen et al. 2000; Miller 1993; Williamson 1979

Duncan 1972; Galbraith 1974

Dill 1958; Duncan 1972; Jauch and Kraft 1986; Lawrence and Lorsch 1967; Thompson 1967; Thompson 1967

Podolny (1994) Hong and Lee (2015)

Chandler 1962; Cyert and March 1963; March and Simon 1958

Noordewier et al. 1990

Anderson and Tushman 2001; Bergh 1998; McGrath 1997;

Weitz and Shenhaav 2000

(i) Koopmans 1957; (ii) Buckley and Carter 1999, 2002

Abdi and Aulakh 2017; Dunn 2010; Mahnke et al. 2007; Williamson 1985; Sutcliffe and Zaheer 1998;

Porter 1980; Sutcliffe and Zaheer 1998

MacCrimmon and Wehrung 1986; Porter 1980; Sutcliffe and Zaheer 1998

Ludvig von Mises 1949

Weitz and Shenhaav 2000

Collet and Philippe 2014; Podolny, 1994

Hong and Lee (2015)

Walker et al. 2013

Mouri at al. 2012

Mahnke et al. 2007

Arrow 1974; Minsky 1996

Keynes 1921

(i) Koopmans 1957; (ii) Buckley and Carter, 1999, 


\begin{tabular}{|c|c|c|}
\hline & $\begin{array}{l}\text { difficulties in combining extant available knowledge in beneficial ways } \\
\text { for the firm because of difficulty in accessing resources or due to } \\
\text { communication inefficiencies }\end{array}$ & 2002 \\
\hline & State uncertainty & Milliken 1987 \\
\hline & Incompleteness of information (i.e. informative uncertainty) & $\begin{array}{l}\text { Anderson and Tushman 2001; Cyert and March } \\
\text { 1963; von Schomberg 1993; Lawrence and } \\
\text { Lorsch 1967; Kaish and Gilad 1991; Thompson } \\
1967\end{array}$ \\
\hline & $\begin{array}{l}\text { Inability to solve complex problems because of human "imperfect } \\
\text { foresight" }\end{array}$ & Keynes 1921; Alchian 1950; Galbraith 1974 \\
\hline & Response uncertainty & Milliken 1987; Conrath 1967; Taylor 1984 \\
\hline & $\begin{array}{l}\text { "Environmental uncertainty" conceptualized as a lack of knowledge for } \\
\text { decision making }\end{array}$ & $\begin{array}{l}\text { Duncan 1972; Cyert and March 1963; Lawrence } \\
\text { and Lorsch 1967; Thompson } 1967\end{array}$ \\
\hline & Value uncertainty & Mahnke et al. 2007 \\
\hline $\begin{array}{l}\text { Degrees of } \\
\text { confidence to deal } \\
\text { with uncertainty. }\end{array}$ & $\begin{array}{l}\text { Subjective uncertainty/state uncertainty/Uncertainty regarding profit } \\
\text { expectations }\end{array}$ & $\begin{array}{l}\text { Lucas 1972, Lucas and Sargent 1981; Hayek } \\
\text { 1948; Helton 1994; Milliken 1987; Minsky 1966; } \\
\text { Penrose 1972; Shackle } 1972\end{array}$ \\
\hline
\end{tabular}

\subsubsection{Uncertainty about the Outcomes of the External Environment}

Uncertainty is often associated with the external environment's outcomes. Decision-makers are assumed to be uncertain either about (i) the distribution of the outcomes (Alvarez 2007; Becker and Knudsen, 2005; Knight 1921; Loasby 1976), or (ii) the assignment of probabilities to each outcome (Carabelli 1998; Keynes 1921; March and Simon, 1958). One of the most widely used terms in the literature to describe uncertainty as stemming from environmental sources is environmental uncertainty (see Downey et al. 1975; Duncan 1972; Jauch and Kraft 1986; Pfeffer and Salancik 1978; Thompson 1967) which is mainly rooted in the complexity and dynamism of the environment (Williamson, 1979). The external environment - at a "macro" level of analysis - is itself a source of uncertainty (Chandler 1962; Cyert and March 1963; March and Simon 1958); this means that at a "micro" level of analysis - unpredictable changes and events affect an exchange (Noordewier et al. 1990). In organization theory (Dill 1958; Duncan 1972; Jauch and Kraft 1986; Lawrence and Lorsch 1967; Thompson 1967) environmental uncertainty is often referred to as perceived environmental uncertainty. Environments are uncertain because actors perceive them as so (Freel 2005). Therefore, the boundary which distinguishes a source of uncertainty as being objectively present in the environment or as subjectively perceived is apparently blurred. Also, the notion of Koopmans' (1957) primary uncertainty refers concurrently to the external environment volatility and to the lack of knowledge about future states of nature (see Penrose 1972).

Perceived uncertainty makes decision-making difficult as it cannot be guided by past experience due to the environment's inherent dynamism (Duncan 1972), producing a lack of information about cause-effect relationships. Similarly, some authors speak about market uncertainty (Podolny 1994; Hong and Lee 2015) or contingent uncertainty (Anderson and Tushman 2001).

Of course, environmental dynamism also affects firm's international operations and growth. In this context, Miller (1993) defines a set of environmental uncertainty sources mainly ascribable to changes that occurred in the market, in industry and in technology. Advancing a similar classification, von Gelderen et al. (2000) argue that the uncertainty faced by the entrepreneur derives from changes in the environment that result from developments in technology, consumer preferences, behaviour of competitors, etc..

In addition, along their life cycle, when new technologies appear on the market, firms face uncertainty over which standard will prevail and if and when to adopt a given technology. This leads to the emergence of the so-called technical uncertainty (Bergh, 1998; McGrath, 1997; Weitz \& Shenhaav, 2000) which is usually associated with mortality of firms and industry's exit rates (Anderson \& Tushman 2001).

Overall, it emerges that environmental uncertainty can at the same time be attributable to the objective indeterminacy of the external environment and to the difficulty of predicting the emergence of events because of 
environmental dynamism (e.g. technological or market changes). In the latter case, the struggle for a decision-maker to predict sets of events, related outcomes, and frequency distributions is attributable to her/his limited knowledge and cognitive capacity to process (internalize) the information received from the environment (Gregoire et al., 2015).

Managing uncertainty is crucial to strategic management and entrepreneurship, where uncertainty must be dealt with not only in the firm's inception phases, but throughout its entire life cycle if it is to maintain a competitive advantage over time. At the same time, market dynamism and changes in technologies are sources of uncertainty that may unveil new opportunities (Hitt et al., 2011) for those entrepreneurial firms, which are able to discover and create new markets, and exploit new technologies. This, in fact, can enable the entry of new firms into the economic system and also opens up opportunities for the renewal of existing ones.

\subsubsection{Uncertainty about Other Actors' Actions}

Rational expectations theory assumes that economic agents are optimal forecasters because they are aware of the model in which they operate, thanks to perfect information and through observing other actors' past behaviour (e.g. Lucas and Sargent 1981). On the contrary, Minsky (1996) argues that because of "bounded rationality", agents are actually unsure of the model in which they operate, and points out that uncertainty arises because of the "myriad of independent agents mak[ing] decisions whose impacts are aggregated into outcomes that emerge over a range of tomorrows" (ibid, p. 360). When assuming bounded rationality, a decision-maker's inability to predict other actors' behaviours and decisions generates uncertainty. According to Transaction Cost Economics (Williamson 1985), behavioural uncertainty (arising from opportunism) is one of the four sources - the other two being environmental uncertainty, asset specificity, and frequency - that determine the choice between market and hierarchy. Behavioural uncertainty stems from the deliberate non-disclosure or misinterpretation of information (Sutcliffe \& Zaheer, 1998). It thus relates to the "informational problems that ensue from the coexistence of bounded rationality and opportunism” (Dunn, 2010, p. 420). Behavioural uncertainty is pervasive inside a firm's activity (see Buckley \& Carter, 1999) as well as in its external relationships. For instance, it may stem from the incomplete understanding of partners' behaviour and conduct (Abdi \& Aulakh, 2017). In this latter case, behavioural uncertainty is comparable to the construct of firm-specific uncertainty which is rooted in a firm's relationships with its partners (Beckamn et al., 2004).

Under the name of cultural uncertainty, Hong and Lee (2015) refer to uncertainty stemming from the opportunism of foreign business partners, and the management of relationships with them. This kind of uncertainty gives rise to status anxiety (Collett \& Philippe, 2014), or - in the context of initial public offerings (IPOs) - to quality uncertainty (Mouri et al., 2012) and to transition uncertainty in the post-IPO era (ibid).

More generally, in the literature, organizational uncertainty is defined as the type of uncertainty originating from human and social relationships (Weitz \& Shenhaav, 2000). It may stem from a series of sources, like for instance dealing with new people (Walker et al., 2013), or from communication issues - under the name of communication uncertainty (Mahnke et al., 2007).

The importance of inter-organizational ties such as alliances or social networks is certainly critical in sustaining the competitive advantage of the firm over time as they promote information-sharing and thus, to some extent, enhance the likelihood of predicting the outcomes of events. At the same time, inter-organisational and social relationships may breed additional sources of uncertainty, which the firm needs to manage (e.g. the types of behavioural, organizational, and communication uncertainty mentioned above). This means that the firm will eventually have to face the impossibility of not knowing others' behaviours - in addition to the outcomes of events. It can be argued that the uncertainty stemming from the behaviour of other actors needs to be inherently considered at the interface of something external (the other actor's behaviour itself) and something internal (the perception of the other actor's behaviour by the decision-maker). This again emphasizes - as in the previously described case of environmental uncertainty - that the boundary between external and internal uncertainty sources is rather blurred.

On the other hand, from a strategic management and entrepreneurship perspective, relationships with other actors are key to exploring and exploiting opportunities (Hitt et al., 2000; Ireland et al., 2002; 2003).

\subsubsection{Uncertainty as Lack of Knowledge}

How do firms manage the impossibility of not knowing outcomes and behaviours through their cognitive structures and knowledge base?

In economics, uncertainty is generally defined as a lack of knowledge about the state of the future (Arrow, 1974; Hirshleifer \& Riley, 1979; Koopmans, 1957; Machina 1987; Milgrom \& Roberts, 1982). It consists in a 
decision-maker's inability to foresee or predict future events given the information they possess at a specific point in time (Alchian, 1950; Keynes, 1937). The notion of incomplete knowledge can be traced back to the so-called marginalist revolution, when Carl Menger stressed that human limits in cognitive capacity are the core source of uncertainty in the production process (Hayek, 1948).

In organizational studies, Milliken's (1987) state uncertainty is uncertainty about the state of the environment: managers perceive it when they do not understand whether and how the components of the environment might change. The notion of state uncertainty seems comparable to that of perceived uncertainty: in both cases external (state) sources are internalized and perceived by decision-makers as something which is not predictable - given extant stocks of knowledge. The same can be said for Milliken's (1987) response uncertainty, a type of uncertainty arising because of a lack of knowledge about the alternatives or response options available (Conrath, 1967; Taylor, 1984). In a similar fashion, secondary uncertainty (as described in Koopmans, 1957, pp. 162-163) refers to inability of managers to communicate because they are not able to combine their actual knowledge in order to determine which actions, that would be beneficial to the firm, should be taken.

In sum, uncertainty resides in the lack of knowledge of decision-makers in (i) predicting the states of the external environment; (ii) how to deal with them; and (iii) necessarily involves that "state" aspects of the environment are perceived and "internalized" via cognitive processes. Again, we shall argue that no neat boundaries exist between the mentioned states of the environment, how are they perceived, interpreted as well as managed given the current stock of knowledge possessed by the decision-maker.

\subsubsection{Degrees of Confidence to Deal with Uncertainty}

Subjective Probability Theory postulates that in the individual's mind, subjective probabilities regarding future prospects at the moment of choice govern future outcomes (March and Simon 1958). Entrepreneurs often confront themselves with value uncertainty that is uncertainty arising from the ambiguity of the assessment process; a lack of clarity about the value of a new initiative (Mahnke et al., 2007). Subjective probabilities are also referred to as subjective uncertainty (Helton 1994), and state uncertainty (Milliken, 1987), both referring to the entrepreneur's confidence in her/his estimates or expectations.

This theme stresses the subjective side of uncertainty, emphasizing decision-makers' personal degrees of confidence in the processes of their assessment and assignment of probabilities to events, hence their confidence in the occurrence of those events. The latter is thus ultimately related to the more general problem of decision-makers' lack of information (Galavotti, 2015) (i.e. unavailability of data that has been given meaning through a relational connection) or knowledge (i.e. unavailability of a collection of information showing a pattern that is useful in understanding a particular issue).

The already mentioned perspective of perceived uncertainty is ascribable also to this theme, but in this case the focus is on how environmental stimuli are perceived by the actors via their cognitive endeavours. The so called "grounded approach to cognition" suggests that opportunities are perceptual experiences (Grégoire et al., 2015). Cognitive systems use environments as "external informational structures that complement internal representations. In turn, internal representations have a situated character, implemented via simulations in the brain's modal systems, making them well suited for interfacing with external structures" (Barsalou, 2010, p. 717). Cognition thus constantly interfaces and interacts with the external environment. Assuming that opportunities are ultimately perceived, entrepreneurs are understood to be able to perform decision-making under uncertainty because they have a different perception of uncertainty compared to non-entrepreneurs (Alvarez et al., 2014; Casson, 1982).

In sum, this theme highlights that (perceived) uncertainty: (i) is a continuum, from complete ignorance to near certainty (McMullen and Shepherd, 2006) attributable to scant knowledge/information when making predictions about outcomes; (ii) is subjective, and ultimately concerns the degree of confidence of decision-makers in judging the likelihood of an event's occurrence, stressing the perceptual and cognitive side of decision-making.

From the above discussion of the themes surrounding uncertainty, it emerges that uncertainty has two interweaving sides to it: there are external factors that are sources of uncertainty, and there is the firm with its bundle of knowledge/information and cognitive structure that has to cope with them.

It emerges that some contributions cannot be clearly and exclusively classified according to Kahneman and Tversky's (1982) external versus internal types of uncertainty. For instance, "environmental" uncertainty can either be classed as an external type of uncertainty if it is understood in its objective dimension (Chandler, 1962; Cyert \& March, 1963; March \& Simon, 1958), or it is ascribable to the internal type of uncertainty when it is conceptualized as a lack of knowledge for decision-making (Duncan, 1972; Cyert \& March, 1963; Lawrence \& 
Lorsch, 1967; Thompson, 1967), for instance in terms of the complexity of information to be processed (Galbraith, 1974). This equivocation may be ascribable to the fact that - as argued in the cognitive perspective of entrepreneurial decision-making - behaviour proceeds from complex interactions between the environment and the mind (Gregoire et al., 2011). This, in turn, is related to how actors experience the environment meaning that uncertainty is perceived (Milliken, 1987). In our view, the issue of perceived uncertainty is particularly critical as it highlights that the boundaries between external and internal uncertainty are not clearly defined.

The mentioned overlaps seem to overcome the understanding of uncertainty as stemming from distinct external or internal sources. In the final section of the paper we provide a conceptualization of uncertainty as a context where the two types of internal and external uncertainty concurrently operate in decision-making processes.

\subsection{Uncertainty in Empirical Studies}

The focus of the following section is to analyse the empirical papers collected, devoting special attention to the topic of perceived uncertainty which, as highlighted in the previous section, emerged critical in the theoretical contributions analyzed. Table 3 systematizes the empirical literature according to our four emerging themes as well as to the different operationalizations and measurements of uncertainty.

\subsubsection{Perceived Uncertainty and Its Measurement: Overlaps with Risk and with Types of Uncertainty}

Many of the collected studies use the two measures of uncertainty which have received widespread attention in the strategic management and organization literature: one by Lawrence and Lorsch (1967) and the other by Duncan (1972). The former - which measures uncertainty associated with a specific job in an organization - was replicated in subsequent studies (e.g. Tosi et al., 1974; Downey et al., 1975). The latter - which measures environmental uncertainty along the dimensions of complexity and dynamism - has been used in subsequent studies (e.g. Gerloff et al., 1991) to measure perceived environmental uncertainty. Downey et al. (1975) examine the conceptual and methodological adequacy of Lawrence and Lorsch and Duncan's scales, and compare them, concluding that both measurements exhibit weaknesses.

The primary shortcoming of Duncan's scale is the aggregation of a range of heterogeneous environmental uncertainties (Miller, 1993) in a single one. Moreover, Duncan (1972) argues that complexity and dynamism are the two crucial environmental factors positively affecting uncertainty perception. In testing such an assumption, Downey et al. (1975) found that complexity is inversely related to uncertainty perception. However, they also found that one of the subscales of Duncan's measure was statistically related to environmental complexity.

The Lawrence and Lorsh scale measured uncertainty over three different organization sub-environments: production, marketing, and research. Milliken (1987) questioned the scale since it is only related to specific jobs in the organization; Tosi et al. (1973) raised concerns over the scales' validity and reliability and have called for a serious re-design of the measure. In 1978 Miles and Snow developed a measure of environmental uncertainty under the name perceived environmental uncertainty scale (PEU). This measure was found to be reliable and valid, but fairly inadequate in terms of stability (see Buchko, 1994).

From Table 3 we observe that some authors specifically refer to uncertainty - instead of risk - and often employ measures of perceived uncertainty (such as Miller's PEU). Some researchers, (Downey et al., 1975; Downey et al., 1977; Tung, 1979) measure both objective and perceived environmental uncertainty and examine the relationship between these two measures. Others like Collet and Philippe (2014), Martin et al (2015), and Mouri et al. (2012) measure market, quality and transition uncertainty, respectively employing measures of (i) market-volatility, (ii) performance-variability (ROA)/market performance based on the capital asset pricing model (CAPM) and (iii) firm sales/venture capitalists backing. Such measures - used by the Authors to operationalize uncertainty - are typically risk-related measures, highlighting that overlaps still occur in the operationalization of risk and uncertainty.

Another finding from the analysis of our set of empirical papers is that internal sources of uncertainty emerge when actors' perceived uncertainty is being investigated. The perspective of perceived uncertainty views environmental variables as stimuli to be perceived by agents (Downey et al., 1975). It highlights how the sources of external uncertainty interweave with internal ones: the former exist objectively, but they are perceived and, perhaps, interpreted and judged by agents. Moreover, looking at this issue from the viewpoint of embedded cognition, environmental factors are stimuli because cognition is "situated", environmentally embedded (Dew et al., 2015). Even if social reality is perceived and interpreted, this does not mean that it is "less real", "it exists in virtue of entrepreneurs' thinking" (Ramoglou \& Zyglidopoulos, 2015, p. 73). The sources of external environmental uncertainty have necessarily to be perceived, "internalized" and "mitigated" through actors' cognition. This phenomenon can be regarded both at the individual and at the collective (firm) level, where 
shared cognition operates to mitigate uncertainty.

Two studies in particular (Duncan, 1972, Priem et al., 2000), regardless of the level of analysis and the methodology, itemize multiple sources of internal and external uncertainty. Decision-makers concurrently face external sources of uncertainty generated by the environment and internal ones, suggesting that there is empirical evidence for claiming that decision-making happens at the interface of external and internal uncertainty.

The abovementioned contrasting findings regarding the validity of measures, coupled with the interchangeable use of measures of risk to assess uncertainty, highlight the presence of a lack of discriminant validity, which means that measures that shall be used to measure two different constructs may actually be correlated (perhaps because of the presence of some latent factors).

The perspective of perceived uncertainty emerging from this set of empirical contributions further highlights that external and internal factors are interweaved. Objective dimensions of the external environment can be perceived differently according to the agent's cognitive frames and endeavours. The former exists objectively, but they are perceived and, perhaps, interpreted and judged by agents. The latter argument, points to the debate over whether opportunities are only perceived - and not objectively available in the external environment - and thus exist subjectively. Opportunities are created in the sense that they "emerge out of the imagination of individuals" (Dimov, 2004, p. 150).

Table 3. Classification of empirical studies according to themes, sources, and measures of uncertainty

\begin{tabular}{|c|c|c|c|c|}
\hline Themes & Sources of uncertainty & Measures of uncertainty & $\begin{array}{l}\text { Level } \\
\text { analysis }\end{array}$ & $\begin{array}{l}\text { Author(s) and } \\
\text { Year }\end{array}$ \\
\hline \multirow{4}{*}{$\begin{array}{l}\text { Uncertainty about } \\
\text { the outcomes of } \\
\text { external } \\
\text { environment }\end{array}$} & $\begin{array}{l}\text { Sources of uncertainty in } \\
\text { international business } \\
\text { (political, } \\
\text { exchange, } \\
\text { production, and output } \\
\text { uncertainties) }\end{array}$ & $\begin{array}{l}\text { Respondents were asked questions regarding the } \\
\text { sources of uncertainty they experienced during the } \\
\text { most recent international project in which they } \\
\text { were involved }\end{array}$ & $\begin{array}{l}\text { Individual } \\
\text { managers }\end{array}$ & $\begin{array}{l}\text { Mascarenhas } \\
(1982)\end{array}$ \\
\hline & $\begin{array}{l}\text { Competitive, input, and } \\
\text { market demand uncertainty }\end{array}$ & $\begin{array}{l}\text { Perceived Environmental Uncertainty is measured } \\
\text { by employing Miles and Snow's } 1978 \text { instrument }\end{array}$ & $\begin{array}{l}\text { Individual } \\
\text { managers }\end{array}$ & Miller (1993) \\
\hline & Technological change & $\begin{array}{l}\text { "Total factor productivity growth (TFP)" is } \\
\text { employed to measure industry-level degrees of } \\
\text { uncertainty }\end{array}$ & $\begin{array}{l}\text { Individual } \\
\text { managers }\end{array}$ & $\begin{array}{l}\text { Sahaym and } \\
\text { Steensma } \\
(2012)\end{array}$ \\
\hline & $\begin{array}{l}\text { Environmental uncertainty, } \\
\text { cultural differences and } \\
\text { other "business difficulties" } \\
\text { in psychically distant } \\
\text { markets }\end{array}$ & $\begin{array}{l}\text { Composite index of both cultural and business } \\
\text { distance is used as a basis for the psychic distance } \\
\text { construct. }\end{array}$ & $\begin{array}{l}\text { Individual } \\
\text { managers }\end{array}$ & $\begin{array}{l}\text { Azar and } \\
\text { Drogendijk } \\
(2014)\end{array}$ \\
\hline \multirow{3}{*}{$\begin{array}{l}\text { Uncertainty about } \\
\text { other actors' } \\
\text { actions }\end{array}$} & $\begin{array}{l}\text { Firm specific uncertainty, } \\
\text { market uncertainty and } \\
\text { environmental uncertainty }\end{array}$ & $\begin{array}{l}\text { Firm specific uncertainty, market uncertainty and } \\
\text { environmental uncertainty are measured through a } \\
\text { measure of performance variability i.e. ROA and } \\
\text { a measure for market performance based on the } \\
\text { capital asset pricing model (CAPM) }\end{array}$ & $\begin{array}{l}\text { Firm level and } \\
\text { market level }\end{array}$ & $\begin{array}{l}\text { Martin et al. } \\
(2015)\end{array}$ \\
\hline & $\begin{array}{l}\text { Primary, competitive, and } \\
\text { supplier uncertainty }\end{array}$ & $\begin{array}{l}\text { Managers were showed case scenarios of a firm } \\
\text { and asked to indicate whether and how they would } \\
\text { use information in making their decisions. }\end{array}$ & Individual & $\begin{array}{l}\text { Sutcliffe and } \\
\text { Zaheer (1998) }\end{array}$ \\
\hline & $\begin{array}{l}\text { Environmental } \\
\text { behavioural }\end{array}$ & $\begin{array}{l}\text { Four-item 5-point semantic differential scale to } \\
\text { measure environmental uncertainty. Four-item } \\
\text { 5-point Likert scale to measure behavioural } \\
\text { uncertainty }\end{array}$ & $\begin{array}{l}\text { Individual } \\
\text { managers }\end{array}$ & $\begin{array}{l}\text { Abdi } \\
\text { Aulakh } \\
(2017)\end{array}$ \\
\hline $\begin{array}{l}\text { Uncertainty about } \\
\text { the outcomes of } \\
\text { external } \\
\text { environment / } \\
\text { Uncertainty about }\end{array}$ & $\begin{array}{l}\text { Market uncertainty } \\
\text { status anxiety }\end{array}$ & $\begin{array}{l}\text { Market volatility to measure market uncertainty } \\
\text { Status anxiety is dependent to the level of market } \\
\text { uncertainty: higher level of market uncertainty } \\
\text { amplifies status anxiety }\end{array}$ & Firm & $\begin{array}{l}\text { Collet and } \\
\text { Philippe } \\
(2014)\end{array}$ \\
\hline
\end{tabular}




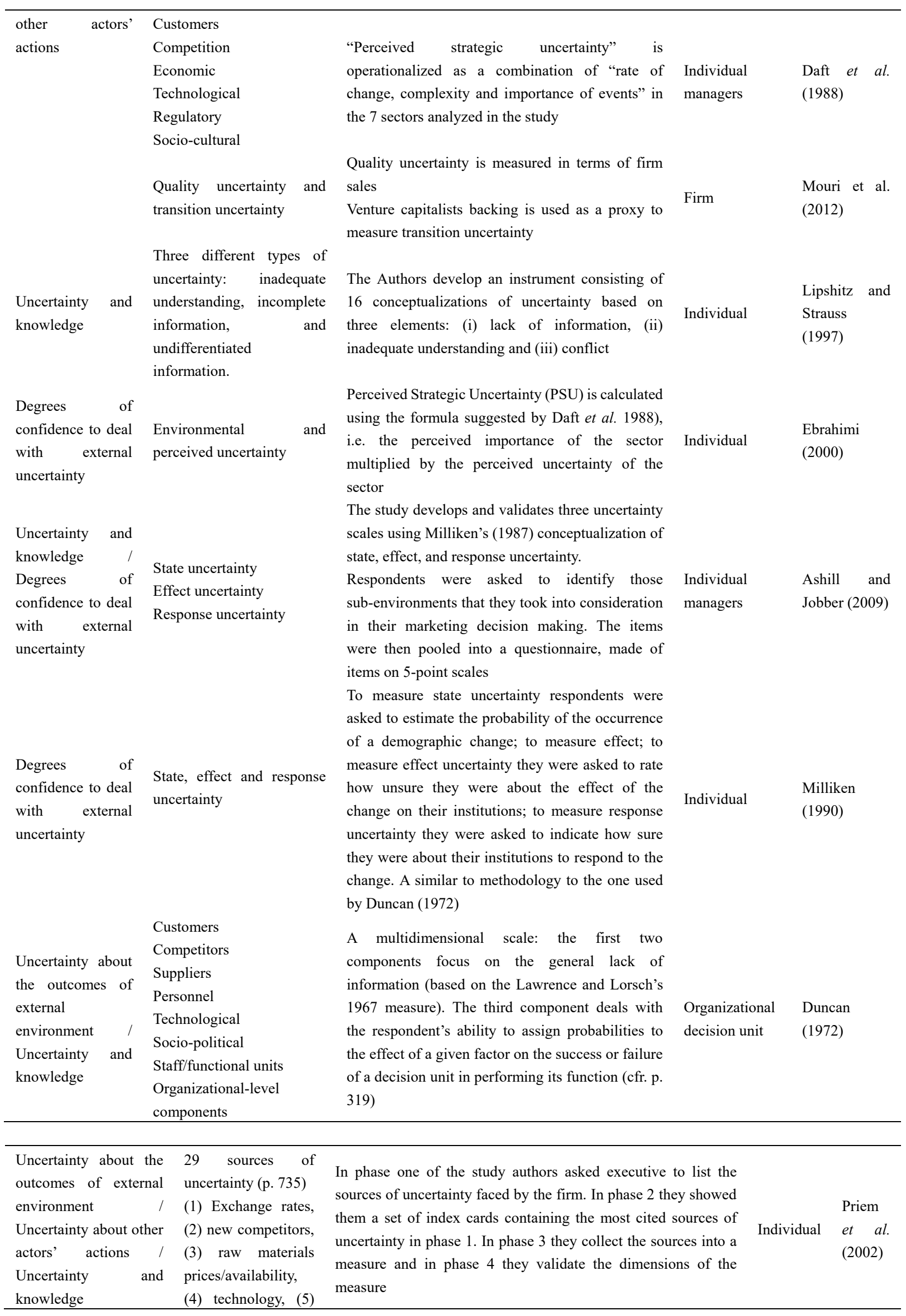




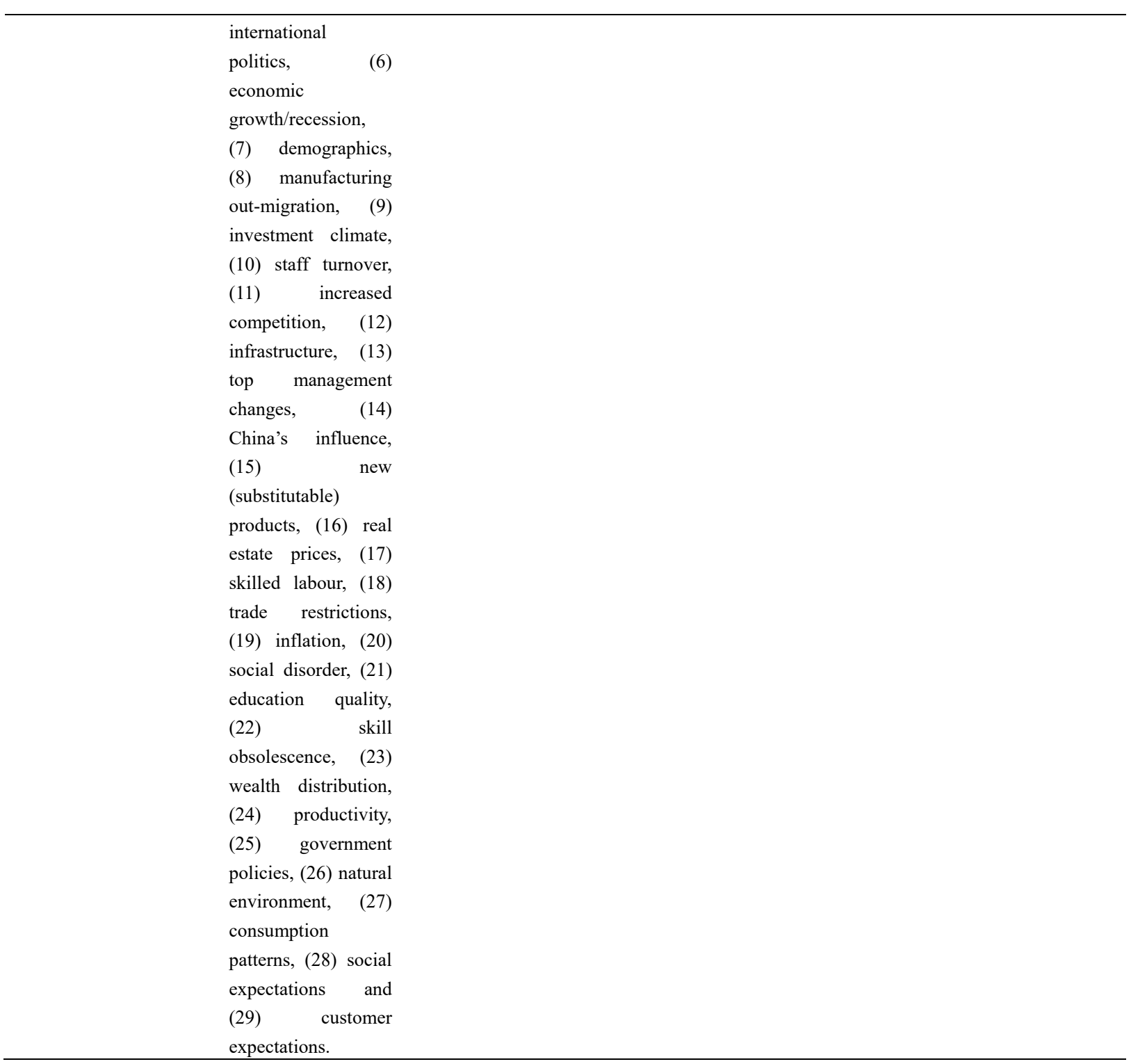

\section{Discussion: A Future Research Agenda for Strategic Management and Entrepreneurship}

We articulate and discuss below some issues that we believe can further advance strategic management and entrepreneurship research with reference to the characterization of uncertainty versus risk, and to the characterization of uncertainty per se. First, we propose to associate uncertainty and risk with the concept of opportunity, which represents a core one in entrepreneurship and - increasingly - in strategic management. Both entrepreneurship and strategic management acknowledge the fundamental role of the processes of opportunities exploration and exploitation for the creation of value (Alvarez, Barney and Anderson 2013). However, the context in which opportunities are formed is still debated. It is also highly debated how opportunities are formed, either through discovery or creation (ibid). We hypothesise that these two issues are intertwined: discussing the role of risk versus uncertainty and its sources may contribute to understand better these processes. We associate uncertainty to situations of opportunity creation, while processes of opportunity recognition, discovery and opportunities exploitation can happen in situations of either - risk or uncertainty (Alvarez and Barney 2005).

Second, we contend the need to understand judgement and decision-making under uncertainty at the interface of internal and external uncertainty. Finally, we outline a model based on how firms manage the intersection of internal with external uncertainty. In doing so, we identify a series of recommendations and opportunities for further research. 


\subsection{Uncertainty versus Risk: Resolution of Conceptual Overlaps through the Concept of Opportunity}

In this contribution, we support the idea that risk and uncertainty are different contexts and should not be treated as synonymous and interchangeable terms. At the same time, we agree that there is a continuum from true uncertainty to risk, and that the two contexts can be either concurrent or subsequent.

We discuss the risk- uncertainty issue in the perspective of opportunities formation and exploitation. The concept of opportunity lies at the heart of entrepreneurship theory (Shane \& Venkataraman, 2000). Though some Authors criticise this concept for its ambiguity (Davidsson, 2015), it still represents a foundation in this field of studies. Part of this criticism is attributable to its elusive nature, which does not sufficiently highlight the nature of entrepreneurial processes in a context of risk and uncertainty. The latter represent the main issues of this contribution and can help in providing a frame for the understanding of the processes of opportunities exploration and exploitation.

Risk and uncertainty can be concurrent, because they can refer to different decision making contexts for different opportunities. For some Authors, a context of opportunity discovery can be associated with a situation embedded in Knightian risk, and a context of opportunity creation with one of Knightian uncertainty (Alvarez \& Barney, 2005; Alvarez et al., 2013). On the one hand, opportunity discovery starts "from a known supply and proceeds in search of an unknown demand, or from a known demand that motivates search for an unknown supply" (Miller, 2007 , p. 62). Both situations of "known supply" or "know demand" are associated with risk because all the relevant information is available to formulate and execute specific plans (Hmieleski et al., 2015), for instance to determine whether the situation provides adequate compensation for the investment (Miller, 2007).

The fact that the discovery of opportunities has to be associated more with risky situations rather than uncertain ones is also suggested by research on expert performance (Baron \& Henry, 2010). Entrepreneurs become increasingly proficient in opportunity discovery because they have gained experience in recognizing complex patterns out of arrays of information (ibid). Such a process involves comparing current opportunities with previously encountered opportunities stored in memory through actively thinking about and reinterpreting available information (Corbett, 2007).

On the other hand, according to the "opportunity creation" perspective (see Alvarez \& Barney, 2007), the nature of the decision-making context is "uncertain" and opportunities are created (Miles \& Snow, 1978) and not given a priori (see Sarasvathy, 2001; Sarasvathy et al., 2008). The process of opportunity creation can be ascribed to situations of uncertainty in the sense that entrepreneurial actions produce effects that generate opportunities that did not previously exist. More specifically, it involves gradual investments, organizing efforts (Alvarez \& Barney, 2005; 2007) and an incremental process of actions, adjustments, reactions (Baron \& Henry, 2010; Barreto, 2012; Sarasvathy, 2001) as well as social interactions (Mainela et al., 2013). Such a conception looks at opportunities to be enacted (Barreto 2012): "planted, nurtured, grown and harvested" (Dew et al., 2015 p. 153) iteratively. The latter view uncovers a process perspective of entrepreneurship (Dimov, 2010; Grégoire et al., 2011; Wood \& McKinley, 2011), where the process of opportunity formation is inherently driven by actions and reactions (Venkataraman et al., 2012).

Nonetheless, it has been argued that enhanced cognitive sources gained through practice and experience can facilitate opportunity creation and not only opportunity discovery (Mainela et al., 2013).

In a strategic entrepreneurship (SE) perspective, the formation (either creation or discovery) of opportunities is followed by their exploitation and is accompanied concurrently by the management of the existing sources of competitive advantage. Entrepreneurial and managerial processes can take place in situations of either risk or uncertainty, which represent distinct contexts of decision making. As we commented in a previous section, strategic entrepreneurship has the merit to encompass different processes, which comprehend opportunities formation and exploitation (entrepreneurship) and the concurrent management of existing competitive advantage (strategic management). This means that firms may take decisions in conditions of both uncertainty (creation of new opportunities), and risk (opportunity discovery, but also commitment and orchestration of resources for opportunities' exploitation and the management of existing competitive advantage).

To different extents and degrees, cognitive endeavours interface with the environment through the process of opportunity evaluation (via judgment) as well as with the processes of opportunity formation. Accordingly, it is important to stress that we are not proposing a clear cut association between opportunity discovery and risk, opportunity creation and uncertainty. Instead, starting from the assumption that risk and uncertainty belong to a continuum - (Hmieleski et al., 2015; Knight, 1921; Rakov \& Newell, 2010), different degrees of confidence in the judgmental processes about opportunities emerge along such a continuum (Miller, 2007; Sanderson, 2012). More specifically, when risk (in the Knightian sense) prevails, a situation of opportunity discovery will then 
prevail, while, when economic action is embedded in uncertainty, a situation of opportunity creation will prevail instead.

In sum, new venture creation as well as its strategic management over time, are interactive processes involving action, but also cognition to interface with the environment to both form and manage opportunities (Reymen et al., 2015). Understanding which sources of uncertainty are related to the process of opportunity formation perhaps mediated by judgment - requires further investigation. We encourage researchers in strategic entrepreneurship to examine in more depth the relationships between risk, uncertainty, and opportunity. Amongst other things, we see an important research avenue in understanding further the relationship between Knightian uncertainty and opportunity creation, in a process of actions and reactions. Moreover, empirical research shall consider advancing novel operationalization of the constructs of risk and uncertainty. In this regard, we think that associating the latter with the concept of opportunity creation may represent a pathway to resolve discriminant validity problems.

\subsection{The Interweaving of Internal and External Uncertainty}

The entrepreneurship literature has long discussed the individual-opportunity nexus (Venkataraman, 1997). The formation of opportunities under risk or uncertainty needs to be concurrently discussed from the perspective of decision makers' perceptions and judgements. The mentioned critique to the opportunity-individual nexus by Davidsson (2015) proposes a conceptualisation based on three constructs: external enablers, new venture ideas and opportunity confidence. The first seems to refer to factors pertaining to the external environment, the second are "imagined future ventures" and the third refers to actors' evaluations about the first two. This proposed re-conceptualisation confirms the need to discuss some foundation of entrepreneurship. At the same time, the interplay of external enablers, the formation of new venture ideas and the judgments processes may benefit from a better understanding of conditions of risk and uncertainty in decision making. We see these processes in their inter-relationships and suggest that they are not neatly separable.

In focusing on uncertainty, as a context of opportunity formation, and particularly of opportunity creation, we similarly highlight what we could label "the actors-uncertainty nexus".

Conceptualizing decision-making under uncertainty as a process embedded into mutually exclusive types of uncertainty - either internal or external - may prove to be conceptually limiting. We contend instead that, along this process, there are overlaps between the two: in many decision-making processes, individuals (or the firm when considering shared cognition) experience a constant confrontation between their cognitive limits and their knowledge base (internal uncertainty) - and the external environment features and instances (external uncertainty (see Gaglio \& Katz, 2001).

From this perspective, decision-making should be understood as a process taking place at the interface between internal and external uncertainty, where the boundaries between the two are not neat.

Only if we accept (the rather unrealistic) assumption of no constraints in knowledge acquisition and learning, then uncertainty could potentially be eliminated (Figueira-de-Lemos et al., 2011). Moreover, the subjective cognitive limits of one decision-maker - compared to those of another - may influence in a negative (or positive) way the ability to understand the features of the external environment, even if external factors are objectively classifiable thanks to the information available.

According to the previously mentioned SE perspective, where entrepreneurial mindsets (cognitions) judge environmental outcome expectancies (Mitchell et al. 2008) to pursue entrepreneurial opportunities, we can argue that external uncertainty is interwoven with the cognitive ability of "coping with it" via judgments. Thus, here, we support the idea that the ability - either at the individual level (entrepreneur, manager) or at the collective level (managerial teams, the firm) - of "judging" the features of the external environment: (1) reduces levels of uncertainty, making mildly unpredictable what is uncertain and (2) this, in turn, positively influences the process of coping with uncertainty, thus paving the way for the creation of opportunities.

We strongly encourage research that investigates the interweaving dynamics of external and internal sources of uncertainty at both the individual and the collective level of analysis, where cognition is distributed in the firm (see Nooteboom 2009). Multi-level empirical research into the interweaving of internal and external uncertainty may provide novel insights in understanding how entrepreneurs, managers, and organizations respond to uncertainty.

It follows a set of research questions that, to the best of our knowledge, have not been addressed yet. What is the extent of the influence exerted by the different members of the firm on the judgmental processes regarding the potential to create opportunities outside definite sources of uncertainty? How do judgmental processes change 
and evolve over time? To what extent do they change as the organizational structure changes too?

Furthermore, we see opportunities for future research in investigating the relationship between processes of judgments, organizational learning and performance: does learning improve the judgmental performance of the firm? To what extent?

\subsection{Coping with Uncertainty at the Interface of External and Internal Uncertainty}

Having discussed the nature of risk and uncertainty and the interweaving nature of the two types of uncertainty, we discuss further the case of opportunity creation in conditions of Knightian uncertainty. We believe this to be a particularly promising perspective of analysis, where the nexus between actors, uncertainty and opportunities can disclose interesting research avenues.

At the interface of internal and external uncertainty individual perceptions and judgements are continually formed and they can give rise to new venture ideas. In literature, the stage of exploration is usually followed by exploitation, through processes of resources mobilisation and orchestration. However, we can hypothesise that this process is not deterministic and strictly sequential: uncertainty is a context in which exploration continues also during the exploitation phase. The mobilisation and orchestration of resources around the new venture/opportunity created generates learning and modifies perceptions and judgements. In this process, uncertainty can also revert into situations of risk, as information becomes available and knowledge advances.

Figure 1 shows the mentioned process in its steps, though- as mentioned above- it is not meant to be a deterministic model. It is instead an illustration of key processes which tend to be iterative and at times overlapping.

(1) At point $t$ in time, the decision-maker perceives new (or modified) sources of uncertainty in the sense that she/he is not able to predict the likelihood of the occurrence of a set of events, nor the associated outcomes.

(2) It follows a process of judgment - that we label internalization of uncertainty - about the mentioned sources. The judgment here is related to the extent to which the source of uncertainty will represent an opportunity (Tang et al. 2012; Wood et al. 2014). The judgmental process may for example involve subjective assessments of desirability and feasibility about the introduction of a new product or service (ibid).

(3) In the affirmative case - whether a source of uncertainty is judged attractive, the firm begins mobilizing resources.

(4) It follows a phase of resource orchestration (Helfat et al., 2007; Sirmon et al., 2011) which is undertaken if new emerging evidence reinforces the judgment about the possibility of exploiting the opportunity which was previously judged attractive. As mentioned above, we are not neglecting the possible emergence of risk within our model. The resource orchestration phase may in fact imply situations embedded in risk and not only in uncertainty. It is in this phase that pure "strategic management" of resources, integrated strategy formulation and implementation of actions occur (Klein et al., 2013). The latter are usually understood in the SE literature as associated with risky situations.

(5) The resource mobilization and orchestration phases further imply the emergence of new or additional sources of uncertainty or generate situations of risk, because of the need to engage in economic activities and social interactions (see e.g. Finch et al., 2012), thus triggering an iterative process.

Our model defines a preliminary phase of (1) judgment which is followed by phases of opportunity exploration $(2,3)$ and then of opportunity exploitation (4): a shift from cognition to action (ibid) through full-scale operations (Choi et al., 2008). Since opportunity exploitation involves a substantial resource commitment, a decision to exploit should depend on whether the associated end state is considered desirable and feasible in the actor's mind (Barreto 2012). Recent studies have strongly supported the idea that a temporal sequence exists from judgment - perhaps via processes of opportunity evaluation (Wood and McKelvie 2015) - to action and enactment (e.g. Grégoire \& Shepherd, 2012; Tumasjan et al., 2012). In sum, the opportunities for generating wealth are created in the entrepreneurial phases (1 to 3 ), while the strategic management phase (4) is "used to match the conditions of an ever-changing market and competitive structure with a firm's continuously evolving resources, capabilities, and core competencies (the sources of strategic inputs)" (Kuratko \& Audretsch, 2009, p. 2).

Our model highlights that the internalization of uncertainty - which is pursued via judgment - is core to the processes of opportunity creation (exploration) and to triggering the following opportunity exploitation. The internalization of uncertainty component is ascribable to one of the so-called entrepreneurial "off-line" cognitive activities (Dew et al., 2015). It is thus antecedent to actual "opportunity objectification" (Wood \& McKinley, 
2010) - the attribution of objective reality to an opportunity idea - and highlights the cognitive aspects related to the role played by cognition in the exploration and exploitation of opportunities (Baldacchino et al., 2015).

Finally, the model considers the balance between exploration and exploitation which some argue is an essential component of SE in dealing with uncertainty (Ireland \& Webb, 2007; Schindehutte and Morris 2009) as well as feedback loops, in line with a conceptualization of SE as iterative (Kyrgidou \& Hughes, 2010). Our contribution thus addresses a call for strong conceptual foundations in SE (Kuratko \& Audretsch, 2009) and for the development of conceptual models to analyse its processes (Kyrgidou \& Hughes, 2010).

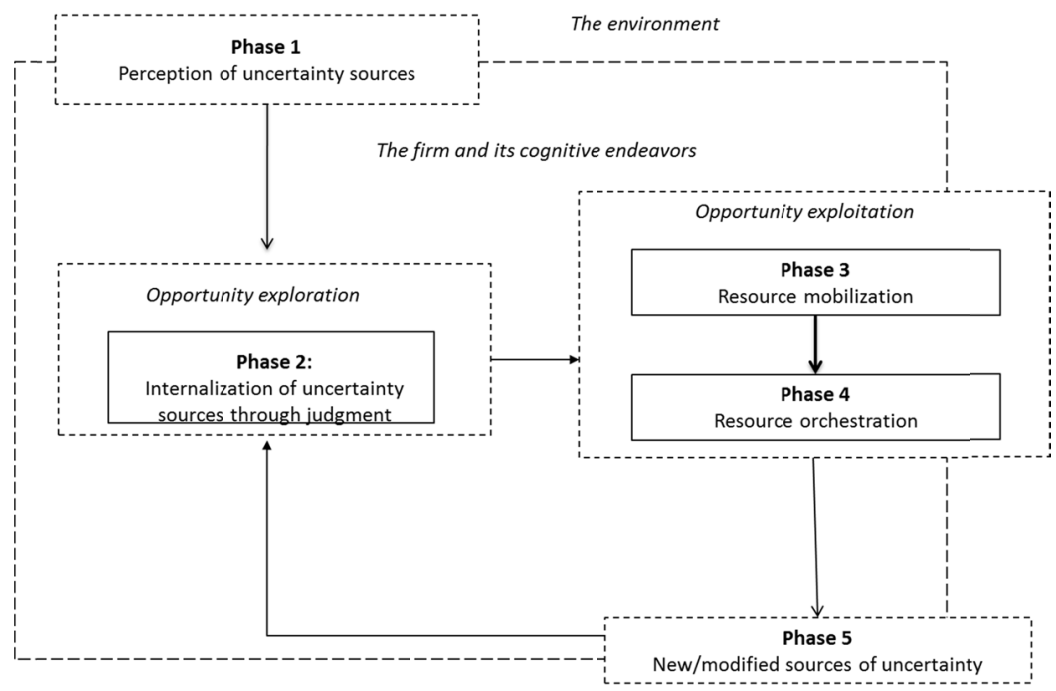

Figure 1. The interface of internal and external uncertainty

Managing the interface of internal and external elements is representative of the firm's ability to cope with uncertainty through the constant confrontation between the external environment and the entrepreneurial cognitive limits (or abilities) in "internalizing" uncertainty, through judgment. Future research could explore the cognitive foundation of the entrepreneurial mindset and action (Ireland et al. 2003), investigating how cognitive adaptability to uncertainty (Haynie et al. 2010, p. 218) - individual or shared - functions when coping with uncertainty and how coping with uncertainty is, in turn, related to the creation of opportunities.

The ability of firms and entrepreneurs to interpret uncertain environments poses a question around a currently underexplored field of research i.e. if and how entrepreneurial cognition interprets - and perhaps judges - the sources of Knightian uncertainty since, by definition, these are instances in which "history does not matter". How do entrepreneurs - or the firm on a collective level - judge whether a source of external Knightian uncertainty represents an opportunity?

\section{Concluding Remarks and Managerial Implications}

The extant review has systematized the management literature on uncertainty to discuss the concept of uncertainty at the crossroads of entrepreneurship and strategic management. In doing so, we have supported the idea of the interweaving of internal and external uncertainty in the process of opportunity formation and enactment. By advancing a framework for managing uncertainty at the interface of external/internal uncertainty, we have introduced the role of uncertainty internalization as the cognitive process which incorporates opportunity evaluation via judgment, and which precedes opportunity exploitation.

We believe this research to support further advances in the emerging field of strategic entrepreneurship, which is thought to be the context in which internal and external sources of uncertainty converge and operate dynamically in decision-making processes.

Firstly, uncertainty needs to be discriminated from risk. While our contribution focuses on the creation of opportunities under uncertainty, we acknowledge that opportunity discovery may happen in conditions of risk, and the same holds for the processes of opportunities exploitation, which follow the discovery/creation phase, and for the management of existing sources of competitive advantage. SE provides an ideal ground for discriminating risk from uncertainty along the mentioned different processes. It also permits to highlight that risk and uncertainty can either characterise concurrently these processes or can evolve from uncertainty towards risk, 
along a continuum. However, risk and uncertainty remain distinct decision-making contexts, that call for further research, especially in the process perspective we suggest.

Secondly, in arguing that decision-making shall not be understood as involving (i) the acknowledgement of, (ii) the focus on, and (iii) the process of coping with definite and distinct sources of external and internal uncertainty, more research is needed in investigating decision-making at the interface between factors stemming from internal and external uncertainty.

Thirdly, in order to manage the interface between external and internal uncertainty, an aspect that remains unexplored are the ways in which cognitive processes of uncertainty internalization operate in interpreting and evaluating sources of external Knightain uncertainty to lay the basis for opportunity formation and enactment.

This contribution has managerial implications too. We contend that decision making should be conceived at the interface between sources of external and internal uncertaint. In this respect, we then argue that entrepreneurial cognitive ability in recognizing and interpreting the environment (i.e. reducing personal levels of internal uncertainty) is a process that engages in a recursive way with that of coping with external uncertainty. The contrast between the initial potential of each human brain and the limits to individual achievement presents a challenge and an opportunity. How the entrepreneur, managers, and the organization respond to uncertainty, is a cognitive process that has not only to be intended at the individual level, but it is also embedded in the firm. This perspective entails entrepreneurs, managers and managerial teams to engage in collective processes to manage uncertainty as a compromise between the individual levels of tolerance to ambiguity and the optimal levels for the business.

\section{References}

Abdi, M., \& Aulakh, P. S. (2017). Locus of uncertainty and the relationship between contractual and relational governance in cross-border interfirm relationships. Journal of Management, 43, 771-803. https://doi.org/10.1177/0149206314541152

Agarwal, R., Audretsch, D., \& Sarkar, M. (2010). Knowledge spillovers and strategic entrepreneurship. Strategic Entrepreneurship Journal, 4, 271-283. https://doi.org/10.1002/sej.96

Alchian, A. A. (1950). Uncertainty, evolution, and economic theory. The Journal of Political Economy, 58, 211-221. https://doi.org/10.1086/256940

Alchian, A. A., \& Demsetz, H. (1972). Production, information costs, and economic organization. The American Economic Review, 1, 777-795. https://doi.org/10.1017/cbo9780511817410.015

Alvarez, S. A. (2007). Entrepreneurial rents and the theory of the firm. Journal of Business Venturing, 22, 427-442. https://doi.org/10.1016/j.jbusvent.2006.04.006

Alvarez, S. A., \& Barney, J. B. (2005). How do entrepreneurs organize firms under conditions of uncertainty? Journal of Management, 31, 776-793. https://doi.org/10.1177/0149206305279486

Alvarez, S. A., \& Barney, J. B. (2007). Discovery and creation: Alternative theories of entrepreneurial action. Strategic Entrepreneurship Journal, 1, 11-26. https://doi.org/10.2139/ssrn.900200

Alvarez, S. A., Barney, J. B., \& Anderson, P. (2013). Forming and exploiting opportunities: The implications of discovery and creation processes for entrepreneurial and organizational research. Organization Science, 24, 301-317. https://doi.org/10.1287/orsc.1110.0727

Alvarez, S., Godley, A., \& Wright, M. (2014). Mark Casson: The entrepreneur at 30-continued relevance?. Strategic Entrepreneurship Journal, 8, 185-194. https://doi.org/10.1002/sej.1180

Anderson, P., \& Tushman, M. L. (2001). Organizational environments and industry exit: The effects of uncertainty, munificence and complexity. Industrial and Corporate Change, 10, 675-711. https://doi.org/10.1093/icc/10.3.675

Arestis, P. (1996). Post-Keynesian economics: towards coherence. Cambridge Journal of Economics, 20, 111-135. https://doi.org/10.1093/oxfordjournals.cje.a013604

Arrow, K. J. (1974). Limited knowledge and economic analysis. American Economic Review, 64, 1-10.

Aulakh, P. S., \& Kotabe, M. (1997). Antecedents and performance implications of channel integration in foreign markets. Journal of International Business Studies, 28, 145-175. https://doi.org/10.1057/palgrave.jibs.8490096

Azar, G., \& Drogendijk, R. (2014). Psychic distance, innovation, and firm performance. Management 
International Review, 54, 581-613. https://doi.org/10.1007/s11575-014-0219-2

Baird, I. S., \& Thomas, H. (1985). Toward a contingency model of strategic risk taking. Academy of Management Review, 10, 230-243. https://doi.org/10.5465/amr.1985.4278108

Balakrishnan, S., \& Wernerfelt, B. (1986). Technical change, competition and vertical integration. Strategic Management Journal, 7, 347-359. https://doi.org/10.1002/smj.4250070405

Baldacchino, L., Ucbasaran, D., Cabantous, L., \& Lockett, A. (2015). Entrepreneurship research on intuition: A critical analysis and research agenda. International Journal of Management Reviews, 17, 212-231. https://doi.org/10.1111/ijmr.12056

Barges, A. (1963). The Effect of Capital Structure on the Cost of Capital. Englewood Cliffs, N.J.: Prentice-Hall.

Barreto, I. (2012). Solving the entrepreneurial puzzle: The role of entrepreneurial interpretation in opportunity formation and related processes. Journal of Management Studies, 49, 356-380. https://doi.org/10.1111/j.1467-6486.2011.01023.x

Barsalou, L. W. (2010). Grounded cognition: past, present, and future. Topics in Cognitive Science, 2, 716-724. https://doi.org/10.1111/j.1756-8765.2010.01115.x

Becker, M. C., \& Knudsen, T. (2005). The role of routines in reducing pervasive uncertainty. Journal of Business Research, 58, 746-757. https://doi.org/10.1016/j.jbusres.2003.10.003

Beckman, C. M., Haunschild, P. R., \& Phillips, D. J. (2004). Friends or strangers? Firm-specific uncertainty, market uncertainty, and network partner selection. Organization Science, 15, 259-275. https://doi.org/10.1287/orsc. 1040.0065

Bentham, J. (1748-1832). The Collected Works of Jeremy Bentham. Oxford: Clarendon Press.

Bergh D. D. (1998). Product-market uncertainty, portfolio restructuring, and performance: An information-processing and resource-based view. Journal of Management, 24, 135-155. https://doi.org/10.1016/s0149-2063(99)80057-9

Bewley, T. F. (2002). Knightian decision theory. Part I. Decisions in Economics and Finance, 25, 79-110. https://doi.org/10.1007/s102030200006

Black, F. (1990). Equilibrium exchange rate hedging. The Journal of Finance, 45, 899-907. https://doi.org/10.3386/w2947

Black, F. (1972). Capital market equilibrium with restricted borrowing. Journal of Business, 45, 444-455. https://doi.org/10.1086/295472

Boland, R. J., Jr., \& Tenkasi, R. V. (1995). Perspective making and perspective taking in communities of knowing. Organization Science, 6, 350-372. https://doi.org/10.1287/orsc.6.4.350

Bourgeois, L. J. (1985). Strategic goals, perceived uncertainty, and economic performance in volatile environments. Academy of Management Journal, 28, 548-573.

Bromiley, P., McShane, M., Nair, A., \& Rustambekov, E. (2015). Enterprise risk management: Review, critique, and research directions. Long Range Planning, 48, 265-276. https://doi.org/10.2139/ssrn.2376261

Brown, C. L., Cavusgil, S. T., \& Lord, A. W. (2015). Country-risk measurement and analysis: A new conceptualization and managerial tool. International Business Review, 24, 246-265. https://doi.org/10.1016/j.ibusrev.2014.07.012

Buchko, A. A. (1994). Conceptualization and measurement of environmental uncertainty: An assessment of the Miles and Snow perceived environmental uncertainty scale. Academy of Management Journal, 37, 410-425. https://doi.org/10.2307/256836

Buckley, P. J., \& Carter, M. J. (1999). Managing cross-border complementary knowledge: conceptual developments in the business process approach to knowledge management in multinational firms. International Studies of Management \& Organization, 29, 80-104. https://doi.org/10.1057/9780230501553_13

Buckley, P. J., \& Carter, M. J. (2002). Process and structure in knowledge management practices of British and US multinational enterprises. Journal of International Management, 8, 29-48. https://doi.org/10.1057/9780230508644_8

Burns, T., \& Stalker, G. M. (1961). The Management of Innovation. London: Tavistock. 
Busenitz, L. W., \& Barney, J. B. (1997). Differences between entrepreneurs and managers in large organizations: Biases and heuristics in strategic decision-making. Journal of Business Venturing, 12, 9-30. https://doi.org/10.1016/s0883-9026(96)00003-1

Butler, J. E. Doktor, R., \& Lins, F. A. (2010). Linking international entrepreneurship to uncertainty, opportunity discovery, and cognition. Journal of International Entrepreneurship, 8, 121-134. https://doi.org/10.1007/s10843-010-0054-x

Camerer, C., \& Weber, M. (1992). Recent developments in modeling preferences: Uncertainty and ambiguity. Journal of Risk and Uncertainty, 5, 325-370. https://doi.org/10.1007/bf00122575

Carabelli, A. (1998). Keynes on probability, uncertainty and tragic choices. Cahiers d'Économie Politique, 30, 187-226. https://doi.org/10.3406/cep.1998.1219

Casson, M. C. (1982). The Entrepreneur: An Economic Theory. Oxford, U.K: Martin Robertson.

Chandler, A. D. (1962). Strategy and Structure: Chapters in the History of the American Enterprise. New York: Doubleday, Anchor Books Edition.

Child, J. (1972). Organizational structure, environment and performance: the role of strategic choice. Sociology, 6, 1-22. https://doi.org/10.1177/003803857200600101

Choi, Y. R., Lévesque, M., \& Shepherd, D. A. (2008). When should entrepreneurs expedite or delay opportunity exploitation? Journal of Business Venturing, 23, 333-355. https://doi.org/10.4337/9781783479801.00011

Collet, F., \& Philippe, D. (2014). From Hot cakes to cold feet: A contingent perspective on the relationship between market uncertainty and status homophily in the formation of alliances. Journal of Management Studies, 51, 406-432. https://doi.org/10.1111/joms.12051

Coddington, A. (1982). Deficient foresight: A troublesome theme in Keynesian economics. American Economic Review, 72, 480-487.

Conrath, D. W. (1967). Organizational decision making behavior under varying conditions of uncertainty. Management Science, 13, 487-500. https://doi.org/10.1287/mnsc.13.8.b487

Covin, J. G., \& Slevin, D. P. (1989). Strategic management of small firms in hostile and benign environments. Strategic Management Journal, 10, 75-87. https://doi.org/10.1002/smj.4250100107

Cyert, R. M., \& March, J. (1963). A Behavioral Theory of the Firm. Englewood Cliffs, NJ: Prentice Hall.

Damodaran, A. (2007). Strategic Risk Taking: A Framework for Risk Management. Upper Saddle River, NJ: Pearson.

Daft, R. L., Sormunen, J., \& Parks, D. (1988). Chief executive scanning, environmental characteristics, and company performance: an empirical study. Strategic Management Journal, 9, 123-139. https://doi.org/10.1002/smj.4250090204

Das, T., \& Teng, B. S. (1996). Risk types and inter-firm alliance structures. Journal of Management Studies, 33 , 827-843. https://doi.org/10.1111/j.1467-6486.1996.tb00174.x

Davidsson, P. (2015). Entrepreneurial opportunities and the entrepreneurship nexus: A re-conceptualization. Journal of Business Venturing, 30, 674-695.

Davis, T. (1993). Effective supply chain management. Sloan Management Review, 34, 35-35.

Denyer, D., \& Tranfield, D. (2008). Producing a systematic review. In D. Buchanan (Ed.), The Sage Handbook of Organizational Research Methods (pp. 671-689). London: Sage.

Dew, N., Grichnik, D., Mayer-Haug, K., Read, S., \& Brinckmann, J. (2015). Situated entrepreneurial cognition. International Journal of Management Reviews, 17, 143-164. https://doi.org/10.1111/ijmr.12051

Dill, W. R. (1958). Environment as an influence on managerial autonomy. Administrative Science Quarterly, 2, 409-443. https://doi.org/10.2307/2390794

Dill, W. R. (1962). The impact of environment on organizational development. In S. Malik and E. H. Van Ness (Eds.), Concepts and Issues in Administrative Behavior (pp. 94-109). Englewood Cliffs, NJ: Prentice Hall,

Dimov, D. (2004). The individuality of opportunity recognition: A critical review and extension. In J. E. Butler (Ed.), Opportunity Identification and Entrepreneurial Behavior (pp. 135-156). Greenwich, CT: Information Age Publishing.

Dimov, D. (2010). Nascent entrepreneurs and venture emergence: Opportunity confidence, human capital, and 
early planning. Journal of Management Studies, 47, 1123-1153. https://doi.org/10.1111/j.1467-6486.2009.00874.x

Douglas, E. J., \& Shepherd, D. A. (2002). Self-employment as a career choice: attitudes, entrepreneurial intentions, and utility maximization. Entrepreneurship Theory and Practice, 26, 81-90. https://doi.org/10.4337/9781783479801.00025

Downey, H. K. (1974). Perceived Uncertainty: conceptual frameworks and research instruments. In Academy of Management Proceedings (No. 1, pp. 54-54). Academy of Management. https://doi.org/10.5465/ambpp.1974.17531402

Downey, H. K., Hellriegel, D., \& Slocum Jr, J. W. (1975). Environmental uncertainty: the construct and its application. Administrative Science Quarterly, 20, 613-629. https://doi.org/10.2307/2392027

Downey, H. K., Hellriegel, D., \& Slocum, J. W. (1977). Individual characteristics as sources of perceived uncertainty variability. Human Relations, 30, 161-174. https://doi.org/10.1177/001872677703000205

Duncan, R. B. (1972). Characteristics of organizational environments and perceived environmental uncertainty. Administrative Science Quarterly, 17, 313-327. https://doi.org/10.2307/2392145

Dunn, S. P. (2000). Fundamental uncertainty and the firm in the long run. Review of Political Economy, 12, 419-433. https://doi.org/10.1080/09538250050175118

Dunn, S. P. (2010). The Uncertain Foundations of Post Keynesian Economics: Essays in Exploration. London: Routledge.

Ebrahimi, B. P. (2000). Perceived strategic uncertainty and environmental scanning behavior of Hong Kong Chinese executives. Journal of Business Research, 49, 67-77. https://doi.org/10.1016/s0148-2963(98)00120-9

Finch, J., Wagner, B., \& Hynes, N. (2012). Resources prospectively: How actors mobilize resources in business settings. Journal of Business Research, 65, 164-174. https://doi.org/10.1016/j.jbusres.2011.05.017

Fitzpatrick, M. (1983). The definition and assessment of political risk in international business: A review of the literature. Academy of Management Review, 8, 249-254. https://doi.org/10.2307/257752

Figueira-de-Lemos, F., Johanson, J., \& Vahlne, J. E. (2011). Risk management in the internationalization process of the firm: A note on the Uppsala model. Journal of World Business, 46, 143-153. https://doi.org/10.1016/j.jwb.2010.05.008

Gabriel, S. C., \& Baker, C. B. (1980). Concepts of business and financial risk. American Journal of Agricultural Economics, 62, 560-564. https://doi.org/10.2307/1240215

Gaglio, C. M., \& Katz, J. A. (2001). The psychological basis of opportunity identification: Entrepreneurial alertness. Small Business Economics, 16, 95-111.

Galavotti, M. C. (2015). Probability theories and organization science the nature and usefulness of different ways of treating uncertainty. Journal of Management, 41, 744-760. https://doi.org/10.1177/0149206314532951.

Galbraith, J. R. (1974). Organization design: An information processing view. Interfaces, 4, 28-36. https://doi.org/10.1287/inte.4.3.28

Gartner, W. B. (1990). What are we talking about when we talk about entrepreneurship?. Journal of Business Venturing, 5, 15-28. https://doi.org/10.4337/9781783476947.00013

Gavetti, G. (2005). Cognition and hierarchy: Rethinking the microfoundations of capabilities' development. Organization Science, 16, 599-617. https://doi.org/10.1287/orsc.1050.0140

Gerloff, E. A., Muir, N. K., \& Bodensteiner, W. D. (1991). Three components of perceived environmental uncertainty: An exploratory analysis of the effects of aggregation. Journal of Management, 17, 749-768. https://doi.org/10.1177/014920639101700408

Ghoshal, S. (1987). Global strategy: An organizing framework. Strategic Management Journal, 8, 425-440. https://doi.org/10.1002/smj.4250080503

Grégoire, D. A., Corbett, A. C., \& McMullen, J. S. (2011). The cognitive perspective in entrepreneurship: An agenda for future research. Journal of Management Studies, 48, 1443-1477. https://doi.org/10.1111/j.1467-6486.2010.00922.x

Grégoire, D. A., Cornelissen, J., Dimov, D., \& Burg, E. (2015). The mind in the middle: Taking stock of affect 
and cognition research in entrepreneurship. International Journal of Management Reviews, 17, 125-142. https://doi.org/10.1111/ijmr.12060

Grégoire, D. A., \& Shepherd, D. A. (2012). Technology-market combinations and the identification of entrepreneurial opportunities: an investigation of the opportunity-individual nexus. Academy of Management Journal, 55, 753-85. https://doi.org/10.4337/9781783479801.00015

Grossman, S. J., \& Hart, O. D. (1986). The costs and benefits of ownership: A theory of vertical and lateral integration. The Journal of Political Economy, 94, 691-719. https://doi.org/10.1086/261404

Hambrick, D. C. (1983). High profit strategies in mature capital goods industries: A contingency approach. Academy of Management Journal, 26, 687-707. https://doi.org/10.2307/255916

Harrison, R. T., \& Leitch, C. M. (2005). Entrepreneurial learning: researching the interface between learning and the entrepreneurial context. Entrepreneurship Theory and Practice, 29, 351-371. https://doi.org/10.1111/j.1540-6520.2005.00089.x

Harvey, C., Kelly, A., Morris, H., \& Rowlinson, M. (2010). The association of business schools. Academic Journal Quality Guide, 4.

Hastie, R. (2001). Problems for judgment and decision making. Annual Review of Psychology, 52, 653-683. https://doi.org/10.1146/annurev.psych.52.1.653

Hayek, F. A. V. (1948). Individualism and Economic Order. Chicago: University of Chicago Press.

Haynie, J. M., Shepherd, D., Mosakowski, E., \& Earley, P. C. (2010). A situated metacognitive model of the entrepreneurial mindset. Journal of Business Venturing, 25, 217-229. https://doi.org/10.1016/j.jbusvent.2008.10.001

Helfat, C. E., Finkelstein, S., Mitchell, W., Peteraf, M., Singh, H., Teece, D., \& Winter, S. (2007). Dynamic Capabilities: Understanding Strategic Change in Organizations. London: Blackwell.

Helton, J. C. (1994). Treatment of uncertainty in performance assessments for complex systems. Risk Analysis, 14, 483-511. https://doi.org/10.1111/j.1539-6924.1994.tb00266.x

Henisz, W. J. (2000). The institutional environment for multinational investment. Journal of Law, Economics, and Organization, 16, 334-364. https://doi.org/10.1093/jleo/16.2.334

Hill, C. W., Hwang, P., \& Kim, W. C. (1990). An eclectic theory of the choice of international entry mode. Strategic Management Journal, 11, 117-128. https://doi.org/10.1002/smj.4250110204

Hirshleifer, J., \& Riley, J. G. (1979). The analytics of uncertainty and information-an expository survey. Journal of Economic Literature, 17, 1375-1421. https://doi.org/10.1017/cbo9781139167635.001

Hitt, M. A., Ireland, R. D., \& Lee, H. U. (2000). Technological learning, knowledge management, firm growth and performance: An introductory essay. Journal of Engineering and Technology Management, 17, 231-246. https://doi.org/10.1016/s0923-4748(00)00024-2

Hitt, M. A., Dacin, M. T., Levitas, E., Arregle, J. L., \& Borza, A. (2000). Partner selection in emerging and developed market contexts: Resource-based and organizational learning perspectives. Academy of Management Journal, 43, 449-467. https://doi.org/10.2307/1556404

Hitt, M. A., Ireland, R. D., Sirmon, D. G., \& Trahms, C. A. (2011). Strategic entrepreneurship: creating value for individuals, organizations, and society. The Academy of Management Perspectives, 25, 57-75. https://doi.org/10.2139/ssrn.1994491

Hmieleski, K. M., Carr, J. C., \& Baron, R. A. (2015). Integrating discovery and creation perspectives of entrepreneurial action: The relative roles of founding CEO human capital, Social capital, and psychological capital in contexts of risk versus uncertainty. Strategic Entrepreneurship Journal, 9, 289-312. https://doi.org/10.1002/sej.1208

Hong, S. J., \& Lee, S. H. (2015). Reducing cultural uncertainty through experience gained in the domestic market. Journal of World Business, 50, 428-438. https://doi.org/10.1016/j.jwb.2014.06.002

Hsu, W. K., Tseng, C. P., Chiang, W. L., \& Chen, C. W. (2012). Risk and uncertainty analysis in the planning stages of a risk decision-making process. Natural Hazards, 61, 1355-1365. https://doi.org/10.1007/s11069-011-0032-1

Humphreys, P., \& Berkeley, D. (1985). Handling uncertainty: Levels of analysis of decision problems. In Wright, G. (Ed.), Behavioral Decision Making. New York: Plenum Press. 
https://doi.org/10.1007/978-1-4613-2391-4_12

Ireland, R. D., \& Webb, J. W. (2007). Strategic entrepreneurship: Creating competitive advantage through streams of innovation. Business Horizons, 50, 49-59. https://doi.org/10.1016/j.bushor.2006.06.002

Ireland, R. D., Hitt, M. A., \& Vaidyanath, D. (2002). Alliance management as a source of competitive advantage. Journal of Management, 28, 413-446. https://doi.org/10.1016/s0149-2063(02)00134-4

Ireland, R. D., Hitt, M. A., \& Sirmon, D. G. (2003). A model of strategic entrepreneurship: The construct and its dimensions. Journal of Management, 29, 963-989. https://doi.org/10.1016/s0149-2063_03_00086-2

Jalonen, H. (2012). The uncertainty of innovation: A systematic review of the literature. Journal of Management Research, 4, 1-47. https://doi.org/10.5296/jmr.v4i1.1039

Jauch, L. R., \& Kraft, K. L. (1986). Strategic management of uncertainty. Academy of Management Review, 11, 777-790. https://doi.org/10.2307/258396

John, C. H. S., Pouder, R. W., \& Cannon, A. R. (2003). Environmental uncertainty and product-process life cycles: A multi-level interpretation of change over time. Journal of Management Studies, 40, 513-541. https://doi.org/10.1111/1467-6486.00349

Jones, O., \& Gatrell, C. (2014). Editorial: The future of writing and reviewing for IJMR. International Journal of Management Reviews, 16, 249-264. https://doi.org/10.1111/ijmr.12038

Kahneman, D., \& Tversky, A. (1982). Variants of uncertainty. Cognition, 11, 143-157. https://doi.org/10.1016/0010-0277(82)90023-3

Kaish, S., \& Gilad, B. (1991). Characteristics of opportunities search of entrepreneurs versus executives: Sources, interests, general alertness. Journal of Business Venturing, 6, 45-61. https://doi.org/10.1016/0883-9026(91)90005-x

Keynes, J. M. (1921) [1957]. A Treatise on Probability. London: MacMillan.

Keynes, J. M. (1937). The general theory of employment. The Quarterly Journal of Economics, 51, 209-223.

Kirzner, I. M. (1979). Perception, Opportunity, and Profit: Studies in the Theory of Entrepreneurship. Chicago: University of Chicago Press.

Klamer, A. (1984). The New Classical Macroeconomics: Conversations with the New Classical Economists and their Opponents. Brigthon: Wheatsheaf Books.

Klein, P. G., Barney, J. B., \& Foss, N. J. (2013). Strategic entrepreneurship. In Kessler, E. H. (Ed.). Encyclopedia of Management Theory. Thousand Oaks: Sage Publications, 779-783.

Klein, S., Frazier, G. L., \& Roth, V. J. (1990). A transaction cost analysis model of channel integration in international markets. Journal of Marketing Research, 27, 196-208. https://doi.org/10.2307/3172846

Knight, F. H. (1921). Risk, Uncertainty and Profit. New York: Hart, Schaffner and Marx.

Knight, D., Pearce, C. L., Smith, K. G., Olian, J. D., Sims, H. P., Smith, K. A., \& Flood, P. (1999). Top management team diversity, group process, and strategic consensus. Strategic Management Journal, 20, 445-465. https://doi.org/10.1002/smj.4250110605

Koopmans, T. C. (1957). Three Essays on the State of Economic Science. New York: McGraw-Hill.

Korsgaard, S., Berglund, H., Thrane, C., \& Blenker, P. (2015). A tale of two Kirzners: Time, uncertainty, and the "nature" of opportunities. Entrepreneurship Theory and Practice. https://doi.org/10.1111/etap.12151

Kuratko, D. F., \& Audretsch, D. B. (2009). Strategic entrepreneurship: exploring different perspectives of an emerging concept. Entrepreneurship Theory and Practice, 33, 1-17. https://doi.org/10.1111/j.1540-6520.2008.00278.x

Kyrgidou, L. P., \& Hughes, M. (2010). Strategic entrepreneurship: origins, core elements and research directions. European Business Review, 22, 43-63.

Lawrence, P. R., \& Lorsch, J. W. (1967). Differentiation and integration in complex organizations. Administrative Science Quarterly, 12, 1-47. https://doi.org/10.2307/2391211

Lawson, T. (1987). The relative/absolute nature of knowledge and economic analysis. The Economic Journal, 97, 951-970. https://doi.org/10.2307/2233082

Lee, R. (2009). Social capital and business and management: Setting a research agenda. International Journal of 
Management Reviews, 11, 247-273. https://doi.org/10.1111/j.1468-2370.2008.00244.x

LeRoy, S. F. and Singell Jr, L. D. (1987). Knight on risk and uncertainty. Journal of Political Economy, 95, 394-406. https://doi.org/10.1086/261461

Liesch, P. W., Welch, L. S., \& Buckley, P. J. (2011). Risk and uncertainty in internationalisation and international entrepreneurship studies. Management International Review, 51, 851-873. https://doi.org/10.1057/9781137402387.0010

Lintner, J. (1965). The valuation of risk assets and the selection of risky investments in stock portfolios and capital budgets. The Review of Economics and Statistics, 47, 13-37. https://doi.org/10.2307/1926735

Lipshitz, R. and Strauss, O. (1997). Coping with uncertainty: A naturalistic decision-making analysis. Organizational Behavior and Human Decision Processes, 69, pp. 149-163. https://doi.org/10.1006/obhd.1997.2679.

Loasby, B. J. (1976). Choice, Complexity, and Ignorance: An Enquiry into Economic Theory and the Practice of Decision-Making. Cambridge: Cambridge University Press.

Loasby, B. J. (2007). A cognitive perspective on entrepreneurship and the firm. Journal of Management Studies, 44, 1078-1106. https://doi.org/10.1111/j.1467-6486.2007.00729.x

Lucas, R. E. (1972). Expectations and the neutrality of money. Journal of Economic Theory, 4, 103-1 23. https://doi.org/10.1016/0022-0531(72)90142-1

Lucas, R. E. and Sargent, T. (1981). After keynesian macroeconomics. Rational Expectations and Econometric Practice, 1, pp. 295-319. https://doi.org/10.4324/9780203443965.ch11

Luce, R. D., \& Raiffa, H. (1957). Games and Decisions. New York: John Wiley Sons.

MacCrimmon, K., \& Wehrung, D. (1986). Taking Risks: The Management of Uncertainty. New York: Free Press.

Machina, M. J. (1987). Decision-making in the presence of risk. Science, 236, 537-543. https://doi.org/10.1126/science.236.4801.537

Macpherson, A., \& Jones, O. (2010). Editorial: strategies for the development of international journal of management reviews. International Journal of Management Reviews, 12, 107-113. https://doi.org/10.1111/j.1468-2370.2010.00282.x

Mahnke, V., Venzin, M., \& Zahra, S. A. (2007). Governing entrepreneurial opportunity recognition in MNEs: Aligning interests and cognition under uncertainty. Journal of Management Studies, 44, 1278-1298. https://doi.org/10.1111/j.1467-6486.2007.00730.x

Mainela, T., Puhakka, V., \& Servais, P. (2014). The concept of international opportunity in international entrepreneurship: a review and a research agenda. International Journal of Management Reviews, 16, 105-129. https://doi.org/10.1111/ijmr.12011

March, J. G., \& Shapira, Z. (1987). Managerial perspectives on risk and risk taking. Management Science, 33, 1404-1418. https://doi.org/10.1287/mnsc.33.11.1404

March, J. G., \& Simon, H. A. (1958). Organizations. New York: Wiley.

Markowitz, H. M. (1952). Portfolio selection. Journal of Finance, 7, 77-91. https://doi.org/10.2307/2975974

Martin, G., Gözübüyük, R., \& Becerra, M. (2015). Interlocks and firm performance: The role of uncertainty in the directorate interlock-performance relationship. Strategic Management Journal, 36, 235-253. https://doi.org/10.1002/smj.2216

Mascarenhas, B. (1982). Coping with uncertainty in international business. Journal of International Business Studies, 13, 87-98. https://doi.org/10.1057/palgrave.jibs.8490552

Matthews, C. H., \& Scott, S. G. (1995). Uncertainty and planning in small and entrepreneurial firms: An empirical assessment. Journal of Small Business Management, 33, 34-52

McKelvie, A., Haynie, J. M., \& Gustavsson, V. (2011). Unpacking the uncertainty construct: Implications for entrepreneurial action. Journal of Business Venturing, 26, 273-292. https://doi.org/10.1016/j.jbusvent.2009.10.004.

McMullen, J. S., \& Shepherd, D. A. (2006). Entrepreneurial action and the role of uncertainty in the theory of the entrepreneur. Academy of Management Review, 31, 132-152. https://doi.org/10.4337/9781783479801.00007. 
Miles, R. E., \& Snow, C. C. (1978). Organizational Strategy, Structure, and Process. New York: McGraw-Hill.

Milgrom, P., \& Roberts, J. (1982). Limit pricing and entry under incomplete information: An equilibrium analysis. Econometrica, 50, 443-459. https://doi.org/10.2307/1912637

Miller, K. D., \& Bromiley, P. (1990). Strategic risk and corporate performance: An analysis of alternative risk measures. Academy of Management Journal, 33, 756-779. https://doi.org/10.2307/256289

Miller, K. D. (1992). A framework for integrated risk management in international business. Journal of International Business Studies, 23, 311-331. https://doi.org/10.1057/palgrave.jibs.8490270

Miller, K. D. (1993). Industry and country effects on managers' perceptions of environmental uncertainties. Journal of International Business Studies, 24, 693-714. https://doi.org/10.1057/palgrave.jibs.8490251

Miller, K. D. (2007). Risk and rationality in entrepreneurial processes. Strategic Entrepreneurship Journal, 1, 57-74. https://doi.org/10.1002/sej.2

Milliken, F. J. (1987). Three types of perceived uncertainty about the environment: State, effect, and response uncertainty. Academy of Management Review, 12, 133-143. https://doi.org/10.2307/257999

Milliken, F. J. (1990). Perceiving and interpreting environmental change: An examination of college administrators' interpretation of changing demographics. The Academy of Management Journal, 33, 42-63. https://doi.org/10.2307/256351

Minsky, H. P. (1996). Uncertainty and the institutional structure of capitalist economies: Remarks upon receiving the Veblen-Commons award. Journal of Economic Issues, 30, 357-368. https://doi.org/10.1080/00213624.1996.11505800

Mises, L. V. (1949). Human Action: A Treatise on Economics. New Heaven: Yale Univeristy Press.

Mitchell, R. K., Mitchell, J. R., \& Smith, J. B. (2008). Inside opportunity formation: enterprise failure, cognition, and the creation of opportunities. Strategic Entrepreneurship Journal, 2, 225-242. https://doi.org/10.1002/sej.51

Mouri, N., Sarkar, M. B., \& Frye, M. (2012). Alliance portfolios and shareholder value in post-IPO firms: The moderating roles of portfolio structure and firm-level uncertainty. Journal of Business Venturing, 27, 355-371. https://doi.org/10.1016/j.jbusvent.2011.02.002

Mousavi, S., \& Gigerenzer, G. (2014). Risk, uncertainty, and heuristics. Journal of Business Research, 67, 1671-1678. https://doi.org/10.1016/j.jbusres.2014.02.013

Nolan, C. T., \& Garavan, T. N. (2016). Human resource development in SMEs: A systematic review of the literature. International Journal of Management Reviews, 18, 85-107. https://doi.org/10.1111/ijmr.12062

Noordewier, T. G., John, G., \& Nevin, J. R. (1990). Performance outcomes of purchasing arrangements in industrial buyer-vendor relationships. The Journal of Marketing, 54, 80-93. https://doi.org/10.2307/1251761

Nooteboom, B. (2005). A cognitive theory of the firm. European Journal of Economic and Social Systems, 18, 29-60. https://doi.org/10.4337/9781848447424

Nooteboom, B. (2009). A Cognitive Theory of the Firm Learning, Governance and Dynamic Capabilities. Cheltenham: Edward Elgar.

Nooteboom, B., Berger H., \& Noorderhaven, N.G. (1997). Effects of trust and governance on relational risk. The Academy of Management Journal, 40, 308-338. https://doi.org/10.2307/256885

O'Reilly, C. A., \& Tushman, M. L. (2008). Ambidexterity as a dynamic capability: Resolving the innovator's dilemma. Research in Organizational Behavior, 28, 185-206. https://doi.org/10.2139/ssrn.978493

O’Reilly, C. A., \& Tushman, M. L. (2013). Organizational ambidexterity: Past, present, and future. Academy of Management Perspectives, 27, 324-338. https://doi.org/10.2139/ssrn.2285704

Penrose, E. T. (1972). The Theory of the Growth of the Firm. Oxford: B. Blackwell.

Petticrew, M., \& Roberts, H. (2008). Systematic Reviews in the Social Sciences: A practical Guide. Malden: Blackwell Publishing.

Pittaway, L., Robertson, M., Munir, K., Denyer, D., \& Neely, A. (2004). Networking and innovation: a systematic review of the evidence. International Journal of Management Reviews, 5, 137-168. https://doi.org/10.1111/j.1460-8545.2004.00101.x 
Pfeffer, J., \& Salancik, G. R. (1978). The External Control of Organizations: A Resource Dependence Approach. New York: Harper and Row Publishers.

Podolny, J. M. (1994). Market uncertainty and the social character of economic exchange. Administrative Science Quarterly, 39, 458-483. https://doi.org/10.2307/2393299

Porter, M. (1980). E. (1980). Competitive Strategy: Techniques for Analyzing Industries and Competitors. New York: Free Press.

Priem, R. L., Love, L. G., \& Shaffer, M. A. (2002). Executives' perceptions of uncertainty sources: A numerical taxonomy and underlying dimensions. Journal of Management, 28, 725-746. https://doi.org/10.1016/s0149-2063(02)00193-9

Rakow, T., \& Newell, B. R. (2010). Degrees of uncertainty: An overview and framework for future research on experience-based choice. Journal of Behavioral Decision Making, 23, 1-14. https://doi.org/10.1002/bdm.681

Ramoglou, S., \& Zyglidopoulos, S. C. (2015). The constructivist view of entrepreneurial opportunities: A critical analysis. Small Business Economics, 44, 71-78. https://doi.org/10.1007/s11187-014-9590-4

Reymen, I., Andriesb, P., Berendsd, H., Mauere, R., \& Stephanf, U. (2015). Understanding dynamics of strategic decision-making in venture creation: A process study of effectuation and causation. Strategic Entrepreneurship Journal, 9, 351-379. https://doi.org/10.1002/sej.1201

Runde, J. (1998). Clarifying Frank Knight's discussion of the meaning of risk and uncertainty. Cambridge Journal of Economics, 22, 539-546. https://doi.org/10.1093/cje/22.5.539

Sahaym, A., Treviño, L. J., \& Steensma, H. K. (2012). The influence of managerial discretion, innovation and uncertainty on export intensity: A real options perspective. International Business Review, 21, 1131-1147. https://doi.org/10.1016/j.ibusrev.2012.01.003

Sanderson, J. (2012). Risk, uncertainty and governance in megaprojects: A critical discussion of alternative explanations. International Journal of Project Management, 30, 432-443. https://doi.org/10.1016/j.ijproman.2011.11.002

Sarasvathy, S. D. (2001). Causation and effectuation: Toward a theoretical shift from economic inevitability to entrepreneurial contingency. Academy of Management Review, 26, 243-263. https://doi.org/10.2307/259121

Sarasvathy, S. D., Dew, N., Read, S., \& Wiltbank, R. (2008). Designing organizations that design environments: Lessons from entrepreneurial expertise. Organization Studies, 29, 331-350. https://doi.org/10.1177/0170840607088017

Sarooghi, H., Libaers, D., \& Burkemper, A. (2015). Examining the relationship between creativity and innovation: A meta-analysis of organizational, cultural, and environmental factors. Journal of Business Venturing, 30, 714-731. https://doi.org/10.1016/j.jbusvent.2014.12.003

Savage L. J. (1954). The Foundations of Statistics. New York: Wiley.

Schendel, D., \& Hitt, M. A. (2007). Introduction to volume 1. Strategic Entrepreneurship Journal, 1, 1-6. https://doi.org/10.1002/sej.16

Schindehutte, M., \& Morris, M. H. (2009). Advancing strategic entrepreneurship research: the role of complexity science in shifting the paradigm. Entrepreneurship Theory and Practice, 33, 241-276. https://doi.org/10.1111/j.1540-6520.2008.00288.x

Schumpeter, J. A. (1934). The Theory of Economic Development. An Inquiry into Profits, Capital, Credit, Interest, and the Business Cycle. London: Transaction Publishers.

Shackle, G. L. S. (1972). Epistemics and Economics: A Critique of Economic Doctrines. New Brunswick: Transaction publications.

Shane, S., \& Eckhardt, J. (2003). The individual-opportunity nexus. In Acs, Z. J. and D. B. Audretsch, D. B. (Eds), Handbook of Entrepreneurship Research. Boston: Kluwer, https://doi.org/10.1007/0-387-24519-7 8.

Shane, S., \& Venkataraman, S. (2000). The promise of entrepreneurship as a field of research. Academy of Management Review, 25, 217-226. https://doi.org/10.1007/3-540-48543-0_8

Sharfman, M. P., \& Dean, J. W. (1991). Conceptualizing and measuring the organizational environment: A multidimensional approach. Journal of Management, 17, 681-700. https://doi.org/10.1177/014920639101700403 
Sharpe, W. F. (1964). Capital asset prices: A theory of market equilibrium under conditions of risk. The Journal of Finance, 19, 425-442. https://doi.org/10.1111/j.1540-6261.1964.tb02865.x

Sirmon, D. G., Hitt, M. A., Ireland, R. D., \& Gilbert, B. A. (2011). Resource orchestration to create competitive advantage breadth, depth, and life cycle effects. Journal of Management, 37, 1390-1412. https://doi.org/10.1177/0149206310385695

Sjoberg, L. (2007). The distortion of beliefs in the face of uncertainty. International Journal of Management and Decision Making, 8, 1-29. https://doi.org/10.1504/ijmdm.2007.012148

Slangen, A. H. and Van Tulder, R. J. (2009). Cultural distance, political risk, or governance quality? Towards a more accurate conceptualization and measurement of external uncertainty in foreign entry mode research. International Business Review, 18, 276-291. https://doi.org/10.1016/j.ibusrev.2009.02.014

Smircich, L. (1983). Concepts of culture and organizational analysis. Administrative Science Quarterly, 28, 339-358. https://doi.org/10.2307/2392246

Solnik, B. H. (1974). An equilibrium model of the international capital market. Journal of Economic Theory, 8, 500-524. https://doi.org/10.1016/0022-0531(74)90024-6

Tang, J., Kacmar, K. M. M., \& Busenitz, L. (2012). Entrepreneurial alertness in the pursuit of new opportunities. Journal of Business Venturing, 27, 77-94. https://doi.org/10.1016/j.jbusvent.2010.07.001.

Taylor, R. N. (1984). Behavioral Decision Making. Glenview, IL: Scott, Foresman.

Thompson, J. D. (1967). Organizations in Action: Social Science Bases of Administrative Theory. New York: McGraw-Hill.

Thorpe, R., Holt, R., Macpherson, A., \& Pittaway, L. (2005). Using knowledge within small and medium-sized firms: A systematic review of the evidence. International Journal of Management Reviews, 7, 257-281. https://doi.org/10.1111/j.1468-2370.2005.00116.x

Tosi, H., Aldag, R., \& Storey, R. (1973). On the measurement of the environment: An assessment of the Lawrence and Lorsch environmental uncertainty subscale. Administrative Science Quarterly, 18, 27-36. https://doi.org/10.2307/2391925

Tranfield, D., Denyer, D., \& Smart, P. (2003). Towards a methodology for developing evidence-informed management knowledge by means of systematic review. British Journal of Management, 14, 207-222. https://doi.org/10.1111/1467-8551.00375

Truitt, J. F. (1974). Expropriation of Private Foreign Investment. Bloomington: Graduate School of Business, Division of Research, University of Indiana.

Tumasjan, A., Welpe, I., \& Spörrle, M. (2013). Easy now, desirable later: The moderating role of temporal distance in opportunity evaluation and exploitation. Entrepreneurship Theory and Practice, 37, 859-888. https://doi.org/10.1111/j.1540-6520.2012.00514.x

Tung, R. L. (1979). Dimensions of organizational environments: An exploratory study of their impact on organization structure. Academy of Management Journal, 22, 672-693. https://doi.org/10.2307/255808

van Horne, J. C. (1974). Fundamentals of Financial Management. Englewood Cliffs, N.J.: Prentice-Hall.

Venkataraman, S. (1997). The distinctive domain of entrepreneurship research. Advances in Entrepreneurship, Firm Emergence and Growth, 3, 119-138.

von Gelderen, M., Frese, M., \& Thurik, R. (2000). Strategies, uncertainty and performance of small business startups. Small Business Economics, 15, 165-181. https://doi.org/10.1023/a:1008113613597

von Schomberg, R. (1993). Controversies and political decision making. In R., von Schomberg (Ed.), Controversies and Political Decision Makin. Dordrecht: Kluwer Academic Publishers. https://doi.org/10.1007/978-94-015-8143-1_2.

Walker, H. J., Bauer, T. N., Cole, M. S., Bernerth, J. B., \& Field, H. S. (2013). Is this how I will be treated? Reducing uncertainty through recruitment interactions. Academy of Management Journal, 56, 1325-1347. https://doi.org/10.5465/ambpp.2012.328

Wang, C. L., \& Chugh, H. (2014). Entrepreneurial learning: Past research and future challenges. International Journal of Management Reviews, 16, 24-61. https://doi.org/10.1111/ijmr.12007

Webster, J., \& Watson, R. T. (2002). Analyzing the past to prepare. Management Information Systems Quarterly, 
$26,13-23$

Weick, K. E., \& Roberts, K. (1993). Collective mind in organizations: Heedful interrelating on flight decks. Administrative Science Quarterly, 38, 357-381. https://doi.org/10.2307/2393372

Weitz, E., \& Shenhaav, Y. (2000). A longitudinal analysis of technical and organizational uncertainty in management theory. Organization Studies, 21, 243-266. https://doi.org/10.1177/0170840600211005

Wernerfelt, B. and Karnani, A. (1987). Competitive strategy under uncertainty. Strategic Management Journal, 8, 187-194. https://doi.org/10.5465/ambpp.1984.4978193

Williamson, O. E. (1979). Transaction-cost economics: The governance of contractual relations. Journal of Law and Economics, 22, 233-261. https://doi.org/10.1086/466942

Williamson, O. E. (1985). The Economic Institutions of Capitalism: Firms, Markets, Relational Contracting. London: Collier Macmillan.

Wood, M. S., McKelvie, A., \& Haynie, J. M. (2014). Making it personal: Opportunity individuation and the shaping of opportunity beliefs. Journal of Business Venturing, 29, 252-272. https://doi.org/10.1016/j.jbusvent.2013.02.001

Wood, M. S., \& McKelvie, A. (2015). Opportunity evaluation as future focused cognition: Identifying conceptual themes and empirical trends. International Journal of Management Reviews, 17, 256-277. https://doi.org/10.1111/ijmr.12053

Wood, M. S., \& McKinley, W. (2010). The production of entrepreneurial opportunity: a constructivist perspective. Strategic Entrepreneurship Journal, 4, 66-84. https://doi.org/10.1002/sej.83

\section{Notes}

Note 1. The total number of papers analysed in the three sections mentioned above is 106 - instead of 96 , as illustrated in Appendix A - because 10 papers are analysed both in the first and in the second section of the study.

\section{Appendix A}

Table A1 List of collected papers per Author, year, Journal and method

\begin{tabular}{|c|c|c|c|c|c|c|}
\hline Author & Year & Journal & Conceptual & $\begin{array}{l}\text { Quantitative } \\
\text { study }\end{array}$ & $\begin{array}{l}\text { Qualitative } \\
\text { study }\end{array}$ & Mixed \\
\hline Keynes & 1921 & The Quarterly Journal of Economics & $\mathrm{X}$ & & & \\
\hline Alchian & 1950 & Journal of Political Economy & $\mathrm{X}$ & & & \\
\hline Koopmans & 1957 & $\begin{array}{l}\text { Econometrica: Journal of the Econometric } \\
\text { Society }\end{array}$ & $\mathrm{X}$ & & & \\
\hline Dill & 1958 & Administrative Science Quarterly & & & $\mathrm{X}$ & \\
\hline Sharpe & 1964 & The Journal of Finance & $\mathrm{X}$ & & & \\
\hline Lintner & 1965 & The Journal of Finance & $\mathrm{X}$ & & & \\
\hline Conrath & 1967 & Management Science & $\mathrm{X}$ & & & \\
\hline $\begin{array}{l}\text { Lawrence and } \\
\text { Lorsch }\end{array}$ & 1967 & Administrative Science Quarterly & & $\mathrm{X}$ & & \\
\hline $\begin{array}{l}\text { Alchian and } \\
\text { Demsetz }\end{array}$ & 1972 & The American Economic Review & $\mathrm{X}$ & & & \\
\hline Black & 1972 & Journal of Business & $\mathrm{X}$ & & & \\
\hline
\end{tabular}




\begin{tabular}{|c|c|c|c|c|c|}
\hline Child & 1972 & Sociology & $\mathrm{X}$ & & \\
\hline Duncan & 1972 & Administrative Science Quarterly & & $\mathrm{X}$ & \\
\hline Lucas & 1972 & Journal of Economic Theory & $\mathrm{X}$ & & \\
\hline Arrow & 1974 & American Economic Review & $\mathrm{X}$ & & \\
\hline Galbraith & 1974 & Interfaces & $\mathrm{X}$ & & \\
\hline Solnik & 1974 & Journal of Economic Theory & $\mathrm{X}$ & & \\
\hline Downey et al. & 1975 & Administrative Science Quarterly & & $\mathrm{X}$ & \\
\hline Downey et al. & 1977 & Human Relations & & $\mathrm{X}$ & \\
\hline Williamson & 1979 & Journal of Law and Economics & $\mathrm{X}$ & & \\
\hline Coddington & 1982 & American Economic Review & $\mathrm{X}$ & & \\
\hline Mascarenhas & 1982 & Journal of International Business Studies & & & $\mathrm{X}$ \\
\hline Fitzpatrick & 1983 & Academy of Management Review & $\mathrm{X}$ & & \\
\hline $\begin{array}{l}\text { Baird and } \\
\text { Thomas }\end{array}$ & 1985 & Academy of Management Review & & $\mathrm{X}$ & \\
\hline $\begin{array}{l}\text { Balakrishnan } \\
\text { and Wernerfelt }\end{array}$ & 1986 & Strategic Management Journal & & $\mathrm{X}$ & \\
\hline $\begin{array}{l}\text { Grossman and } \\
\text { Hart }\end{array}$ & 1986 & The Journal of Political Economy & $\mathrm{X}$ & & \\
\hline $\begin{array}{l}\text { Jauch and } \\
\text { Kraft }\end{array}$ & 1986 & Academy of Management Review & $\mathrm{X}$ & & \\
\hline Ghoshal & 1987 & Strategic Management Journal & $\mathrm{X}$ & & \\
\hline Lawson & 1987 & The Economic Journal & $\mathrm{X}$ & & \\
\hline $\begin{array}{l}\text { Wernerfelt and } \\
\text { Karnani }\end{array}$ & 1987 & Strategic Management Journal & $\mathrm{X}$ & & \\
\hline $\begin{array}{l}\text { LeRoy and } \\
\text { Singell }\end{array}$ & 1987 & Journal of Political Economy & $\mathrm{X}$ & & \\
\hline $\begin{array}{l}\text { March and } \\
\text { Shapira }\end{array}$ & 1987 & Management Science & $\mathrm{X}$ & & \\
\hline Milliken & 1987 & Academy of Management Review & $\mathrm{X}$ & & \\
\hline Daft et al. & 1988 & Strategic Management Journal & & & $\mathrm{X}$ \\
\hline Black & 1990 & The Journal of Finance & $\mathrm{X}$ & & \\
\hline Gartner & 1990 & Journal of Business Venturing & & $\mathrm{X}$ & \\
\hline Hill et al. & 1990 & Strategic Management Journal & $\mathrm{X}$ & & \\
\hline Klein et al. & 1990 & Journal of Marketing Research & & $\mathrm{X}$ & \\
\hline $\begin{array}{l}\text { Miller and } \\
\text { Bromiley }\end{array}$ & 1990 & Academy of Management Journal & & $\mathrm{X}$ & \\
\hline
\end{tabular}




\begin{tabular}{|c|c|c|c|c|c|}
\hline $\begin{array}{l}\text { Noordewier et } \\
\text { al. }\end{array}$ & 1990 & Journal of Marketing & & $\mathrm{X}$ & \\
\hline $\begin{array}{l}\text { Kaish and } \\
\text { Gilad }\end{array}$ & 1991 & Journal of Business Venturing & & $\mathrm{X}$ & \\
\hline Miller & 1992 & Journal of International Business Studies & $\mathrm{X}$ & & \\
\hline Davis & 1993 & Sloan Management Review & & & $\mathrm{X}$ \\
\hline Miller & 1993 & Journal of International Business Studies & & & $\mathrm{X}$ \\
\hline Buchko & 1994 & Academy of Management Journal & & $\mathrm{X}$ & \\
\hline Helton & 1994 & Risk Analysis & & $\mathrm{X}$ & \\
\hline Podolny & 1994 & Administrative Science Quarterly & $\mathrm{X}$ & & \\
\hline Das and Teng & 1996 & Journal of Management Studies & $\mathrm{X}$ & & \\
\hline Minsky & 1996 & Journal of Economic Issues & $\mathrm{X}$ & & \\
\hline Arestis & 1996 & Cambridge Journal of Economics & $\mathrm{X}$ & & \\
\hline $\begin{array}{l}\text { Nooteboom et } \\
\text { al. }\end{array}$ & 1997 & Academy of Management Journal & & $\mathrm{X}$ & \\
\hline Bergh & 1998 & Journal of Management, & & $\mathrm{X}$ & \\
\hline $\begin{array}{l}\text { Sutcliffe and } \\
\text { Zaheer }\end{array}$ & 1998 & Strategic Management Journal & & $\mathrm{X}$ & \\
\hline Runde & 1998 & Cambridge Journal of Economics & $\mathrm{X}$ & & \\
\hline $\begin{array}{l}\text { Buckley and } \\
\text { Carter }\end{array}$ & 1999 & $\begin{array}{l}\text { International Studies of Management and } \\
\text { Organization }\end{array}$ & $\mathrm{X}$ & & \\
\hline Dunn & 2000 & Review of Political Economy & $\mathrm{X}$ & & \\
\hline Ebrahimi & 2000 & Journal of Business Research & & & $\mathrm{X}$ \\
\hline Henisz & 2000 & $\begin{array}{l}\text { Journal of Law, Economics, and } \\
\text { Organization }\end{array}$ & & $\mathrm{X}$ & \\
\hline $\begin{array}{l}\text { von Gelderen } \\
\text { et al. }\end{array}$ & 2000 & Small Business Economics & & $\mathrm{X}$ & \\
\hline $\begin{array}{l}\text { Weitz and } \\
\text { Shenhaav }\end{array}$ & 2000 & Organization Studies & & $\mathrm{X}$ & \\
\hline $\begin{array}{l}\text { Anderson and } \\
\text { Tushman }\end{array}$ & 2001 & Industrial and Corporate Change & & $\mathrm{X}$ & \\
\hline $\begin{array}{l}\text { Gaglio and } \\
\text { Katz }\end{array}$ & 2001 & Small Business Economics & & $\mathrm{X}$ & \\
\hline Hastie. & 2001 & Annual Review of Psychology & $\mathrm{X}$ & & \\
\hline Sarasvathy & 2001 & Academy of Management Review & $\mathrm{X}$ & & \\
\hline Bewley & 2002 & Decisions in Economics and Finance & $\mathrm{X}$ & & \\
\hline $\begin{array}{l}\text { Buckley and } \\
\text { Carter }\end{array}$ & 2002 & Journal of International Management & $\mathrm{X}$ & & \\
\hline
\end{tabular}




\begin{tabular}{|c|c|c|c|c|c|}
\hline $\begin{array}{l}\text { Douglas and } \\
\text { Shepherd }\end{array}$ & 2002 & Entrepreneurship Theory and Practice & & & $\mathrm{X}$ \\
\hline Priem et al. & 2002 & Journal of Management & & $\mathrm{X}$ & \\
\hline Beckman et al. & 2004 & Organization Science & & $\mathrm{X}$ & \\
\hline John et al. & 2003 & Journal of Management Studies & $\mathrm{X}$ & & \\
\hline $\begin{array}{l}\text { Becker and } \\
\text { Knudsen }\end{array}$ & 2005 & Journal of Business Research & & $\mathrm{X}$ & \\
\hline $\begin{array}{l}\text { Harrison and } \\
\text { Leitch }\end{array}$ & 2005 & Entrepreneurship Theory and Practice & $\mathrm{X}$ & & \\
\hline $\begin{array}{l}\text { McMullen and } \\
\text { Shepherd }\end{array}$ & 2006 & Academy of Management Review & $\mathrm{X}$ & & \\
\hline Alvarez & 2007 & Journal of Business Venturing & $\mathrm{X}$ & & \\
\hline Loasby & 2007 & Journal of Management Studies & $\mathrm{X}$ & & \\
\hline Mahnke et al. & 2007 & Journal of Management Studies & $\mathrm{X}$ & & \\
\hline Sjoberg & 2007 & $\begin{array}{l}\text { International Journal of Management and } \\
\text { Decision Making }\end{array}$ & & $\mathrm{X}$ & \\
\hline $\begin{array}{l}\text { Sarasvathy et } \\
\text { al. }\end{array}$ & 2008 & Organization Studies & $\mathrm{X}$ & & \\
\hline $\begin{array}{l}\text { Ashill and } \\
\text { Jobber }\end{array}$ & 2009 & Journal of Management & & & $\mathrm{X}$ \\
\hline $\begin{array}{l}\text { Slangen and } \\
\text { Van Tulder. }\end{array}$ & 2009 & International Business Review & & $\mathrm{X}$ & \\
\hline Butler et al. & 2010 & Journal of International Entrepreneurship & $\mathrm{X}$ & & \\
\hline $\begin{array}{l}\text { Figueira-de-Le } \\
\text { mos et al. }\end{array}$ & 2011 & Journal of World Business & $\mathrm{X}$ & & \\
\hline Hitt et al. & 2011 & Academy of Management Perspectives & $\mathrm{X}$ & & \\
\hline $\begin{array}{l}\text { McKelvie et } \\
\text { al. }\end{array}$ & 2011 & Journal of Business Venturing & & $\mathrm{X}$ & \\
\hline Hsu et al. & 2012 & Natural Hazards & $\mathrm{X}$ & & \\
\hline Mouri at al. & 2012 & Journal of Business Venturing & & $\mathrm{X}$ & \\
\hline Sahaym, et al. & 2012 & International Business Review & & $\mathrm{X}$ & \\
\hline Walker et al. & 2013 & Academy of Management Journal & & & $\mathrm{X}$ \\
\hline $\begin{array}{l}\text { Azar and } \\
\text { Drogendijk }\end{array}$ & 2014 & Management International Review & & $\mathrm{X}$ & \\
\hline Bromiley et al. & 2015 & Long Range Planning. & $\mathrm{X}$ & & \\
\hline $\begin{array}{l}\text { Collet and } \\
\text { Philippe }\end{array}$ & 2014 & Journal of Management Studies & & $\mathrm{X}$ & \\
\hline $\begin{array}{l}\text { Mousavi and } \\
\text { Gigerenzer }\end{array}$ & 2014 & Journal of Business Research. & $\mathrm{X}$ & & \\
\hline
\end{tabular}




\begin{tabular}{|c|c|c|c|c|}
\hline Hong and Lee & 2015 & Journal of World Business. & & $\mathrm{X}$ \\
\hline Galavotti & 2015 & Journal of Management & $\mathrm{X}$ & \\
\hline Martin et al. & 2015 & Strategic Management Journal & & $\mathrm{X}$ \\
\hline Sarooghi et al. & 2015 & Journal of Business Venturing, & & $\mathrm{X}$ \\
\hline \multirow{3}{*}{$\begin{array}{l}\text { Abdi and } \\
\text { Aulakh }\end{array}$} & 2017 & Journal of Management & & $\mathrm{X}$ \\
\hline & $\mathrm{TOT}=52$ & $\mathrm{TOT}=35$ & TOT $=7$ & TOT $=2$ \\
\hline & $\mathrm{TOT}=96$ & & & \\
\hline
\end{tabular}

\section{Appendix B \\ Papers' inclusion and exclusion criteria}

We perform an exploratory query using ProQuest, IEEE and Google Scholar. While ProQuest was used to search for dissertations and books, IEEE Xplore was employed to search for Working Papers, Conference Papers and Proceedings. Google Scholar was used to include a number of additional papers that were relevant to our research (Petticrew and Roberts 2008).

We conduct a full-text search from 1921 up until the beginning of 2015, using the following keywords: "uncertainty economics", "uncertainty management" "uncertainty internationalization", "uncertainty business", "uncertainty firm", "uncertainty organization", "uncertainty literature", "uncertainty review" "uncertainty strategic management", "uncertainty organization literature", "uncertainty entrepreneurship". And then, "risk economics", "risk management", "risk internationalization", "risk business", "risk firm", "risk organization", "risk literature", "risk review" "risk strategic management", "risk organization literature", "risk and uncertainty entrepreneur". Then we proceed by conducting another search including the Boolean search operator "AND" was then performed for each of the former sentences combining "risk" AND "uncertainty" AND e.g. "management".

The described query yielded over 7.000.000 results, thus we decide to apply a series of inclusion and exclusion criteria following the most recent SLR practices (see Nolan and Garavan 2016). Firstly, we proceed by focusing on peer-reviewed academic journal articles listed in the ABS Academic Journal Quality Guide, Version 4 (Harvey et al. 2010) in order to limit the review both in terms of "quality standard journals" and number of papers to be reviewed (Pittaway, Robertson, Munir, Denyer and Neely 2004). Conference and working papers were excluded.

Secondly, we retrieved articles published in the following subcategories viz. "General Management", "Economics", "Entrepreneurship and Small Business Management", "Organization Studies", "Social Science", "Strategic Management" as primary literature sources, and "Psychology, "Operation Research and Management Science", "International Business and Area Studies", "Marketing", and "Finance" as secondary literature sources. The Journals selected as primary and secondary literature sources were thought to be representative of the most influential articles in the cited fields.

Three Journals do not belong to this list: Natural Hazards, Decisions in Economics and Finance, and Journal of Business. We decided to maintain the articles belonging to these journals because - following the "go backwards" practice (Webster and Watson 2002) - we found them to be repeatedly and extensively cited in the literature collected in the previously described step.

Thirdly, in these selected Journals we searched the Title and Abstract using the key Boolean search terms *uncertainty AND * risk between 1921 and 2015 (for journals published later than 1921, the search was restricted from the date of first issue to 2015). We applied the following inclusion criteria to ensure that each article fell within the set research objectives and conceptual boundaries. In terms of theoretical contributions, the articles included provided insights into one or more of the following issues:

(1) a definition and/or a characterization of uncertainty,

(2) a definition and/or a characterization of risk,

(3) a definition or a model of uncertainty in relation/as opposed to risk, 
(4) a framework of uncertainty in relation to the construct of probability,

(5) a framework of uncertainty in relation to knowledge,

(6) the relationship between uncertainty and business,

(7) the relationship between uncertainty and the firm,

(8) the relationship between uncertainty and entrepreneurship.

In terms of empirical papers, (9) we kept those investigating topics 1 to 5 above, and those enumerating: (i) actual sources of uncertainty in entrepreneurial and business activity; (ii) scales used to measure (perceived) risk/uncertainty.

We ended up with 22.734 papers and divided our studies into four categories; A, B and C lists (see Nolan and Garavan 2016; Thorpe et al. 2005). Categories 'A' were studies that were highly relevant to one or more of the nine topics mentioned above. Category ' $\mathrm{B}$ ' was defined as studies where the relevance was unclear. Category ' $\mathrm{C}$ ' included studies that were less relevant or not relevant at all.

1100 papers were considered to be relevant in terms of contribution to the discussion related to understanding uncertainty in business management (see Lee 2009). 1005 contributions -including those containing the key search terms - were labelled "Category B" or "Category C" because they did not focus on or provide a meaningful discussion that was relevant to the objectives of our study. The 96 "Category A" articles were those included in the review.

1003 articles were excluded as they fell outside the conceptual boundaries of the study. (1) "Category B" articles were excluded because they did not provide either: (i) a clear definition of risk (ii) a clear definition of uncertainty; (iii) a clear characterization of uncertainty as opposed to risk; (iv) a clear characterization of uncertainty as itself. (2) "Category C" articles that contained the keywords of the search parameters but did not provide a substantive discussion of risk and uncertainty and their characterization.

\section{Appendix C}

\section{Collected books}

Given the topic addressed by our review, we decided to include books too. These were retrieved by conducting the following types of search: (i) a manual search of the most relevant contributions held by the library of our Department of Economics and Management, (ii) a search made through the "going backward" and "going forward" techniques (Webster and Watson 2002) in the papers collected (see Appendices A and B).

The inclusion of books (see Table C1) was essential because due to their scholarly status, these are (see Lee, 2009) fundamental pieces of research on risk and uncertainty as well as probability and knowledge, the treatment of which is embedded within the understanding of the theory of risk and uncertainty. This is especially evident in the cases of those books published between 1921 and the 1980s, for instance Knight (1921), Keynes (1921), Hayek (1948), Koopmans (1957); Luce and Raiffa (1957) Ludvig von Mises (1949), Loasby (1976).

Table C1. List of collected books per Author and year

\begin{tabular}{ll}
\hline Author & Year \\
\hline Knight & 1921 \\
Schumpeter & 1934 \\
Hayek & 1948 \\
Mises (von) & 1949 \\
Luce and Raiffa & 1957 \\
March and Simon & 1958 \\
Chandler & 1962 \\
Barges & 1963 \\
Cyert and March & 1963 \\
Thompson & 1967 \\
\hline
\end{tabular}




\begin{tabular}{|c|c|}
\hline Penrose & 1972 \\
\hline Shackle & 1972 \\
\hline Truitt & 1974 \\
\hline van Horne & 1974 \\
\hline Loasby & 1976 \\
\hline Galbraith & 1977 \\
\hline Miles and Snow & 1978 \\
\hline Pfeffer and Salancik & 1978 \\
\hline Kirzner & 1979 \\
\hline Porter & 1980 \\
\hline Lucas and Sargent & 1981 \\
\hline Taylor & 1984 \\
\hline Humphreys and Berkley* & 1985 \\
\hline Williamson & 1985 \\
\hline MacCrimmon and Wehrung & 1986 \\
\hline Carabelli & 1988 \\
\hline von Schomberg & 1993 \\
\hline Damodaran & 2007 \\
\hline Dunn & 2010 \\
\hline \multicolumn{2}{|c|}{$\mathrm{TOT}=28$ books, 1 book chapter } \\
\hline * Book chapter & \\
\hline
\end{tabular}

\section{Copyrights}

Copyright for this article is retained by the author(s), with first publication rights granted to the journal.

This is an open-access article distributed under the terms and conditions of the Creative Commons Attribution license (http://creativecommons.org/licenses/by/4.0/). 